\title{
Dergiabant
}

Cilt/Volume: 9, Sayı/Issue: 1

(Mayıs/May 2021)

\section{Kur'ân'da “Selâm Olsun!” İfadesiyle Esenliğe Mazhar Olacağı Belirtilen Davranışlar}

\section{Behaviors that are Indicated to Be Led to Well-Being through Expressing "Peace Be Upon You!" in the Qur'ān}

\author{
Şuayip Karataş \\ Dr. Öğr. Üyesi, Aksaray Üniversitesi, İslami İlimler Fakültesi, \\ Kur'an- Kerim Okuma ve Kıraat İlmi Anabilim Dalı \\ Asst. Prof. Dr., Aksaray University, Faculty of Islamic Sciences, \\ Department of Quran Reciting and Qiraat Science \\ Aksaray/Turkey \\ suaybk@hotmail.com \\ orcid.org/0000-0002-8261-1491 \\ Makale Bilgisi Article Information
}

Makale Türü: Araştırma Makalesi

Geliş Tarihi: 7 Ocak 2021

Kabul Tarihi: 15 Mart 2021

Yayın Tarihi: 30 Mayıs 2021

Yayın Sezonu: Bahar
Article Type: Research Article

Date Received: 7 January 2021

Date Accepted: 15 March 2021

Date Published: 30 May 2021

Publication Season: Spring

https://doi.org/10.33931/abuifd.856138

İntihal/Plagiarism

Bu makale özel bir yazılımla taranmış ve intihal tespit edilmemiştir. This article has been scanned by a special software and no plagiarism detected.

\section{Atıf/Cite as}

Karataş, Şuayip. “Kur'ân'da 'Selâm Olsun!' İfadesiyle Esenliğe Mazhar Olacağı Belirtilen Davranışlar". Dergiabant 9/1 (Mayıs 2021), 151-177.

$$
\text { https://doi.org/10.33931/abuifd.856138 }
$$

Copyright $\odot$ Published by Bolu Abant Izzet Baysal University Faculty of Theology, Bolu, 14030 Turkey. All rights reserved. https://dergipark.org.tr/tr/pub/dergiabant 


\title{
Kur'ân'da “Selâm Olsun!” İfadesiyle Esenliğe Mazhar Olacağı Belirtilen Davranışlar
}

\begin{abstract}
Öz
İslâm inancına göre bu dünyada yaşananlar bu dünyayla sınırlı kalmayacak, yaşantının karşılığı olarak ahirette görülecektir. Bu husus Kur'ân'da, insanların bu dünyadaki yaşantılarının keyfiyetine göre ahirette çeşitli mükâfat veya ceza ile karşılaşacakları şeklinde ifade edilmektedir. Buna göre, dünyada Allah Teâlâ'nın istediği şekilde yaşayıp cenneti kazanacaklara verilecek büyük mükâfatlardan birinin, ahirette selâm sözüyle karşılanma olduğu haber verilmektedir. Kur'ân'da insana Allah'ın hoşnutluğunu kazandıracak bazı davranışlardan da övgüyle veya farklı üslûpla bahsedilmektedir. Bunlardan biri de "selâm olsun!" denilerek, bazı davranışların sahiplerine esenlik niyazında bulunulmasıdır. İlgili âyetlerde, bu davranışların Allah katında daha sevimli olduğuna dikkat çekilmektedir. Bu durum, Kur'ân'da esenlik dilemek maksadıyla, bazı peygamberlere veya yapılan bir davranış üzerinden o davranışı yapanlara gıyaben "selâm olsun!" șeklindeki temenniyi de kapsamaktadır. Çalışmada öncelikle, selâm kelimesi, sözlük ve terim anlamlarıyla tahlil edilmiş, ardından, selâm kelimesinin Kur'ân'da geçme keyfiyeti hakkında bilgiler verilmiştir. Daha sonra ise Kur'ân'da, "selâm olsun!" denilmek suretiyle esenlik dilenmeye layık görülen davranışlar tespit edilerek bazı örnekler üzerinden durum tespiti yapılmaya çalışılmıştır.
\end{abstract}

Anahtar Kelimeler: Tefsir, Kur'ân, Selâm, Esenlik, Davranış.

\section{Behaviors that are Indicated to Be Led to Well-Being through Expressing "Peace Be Upon You!" in the Qur'ān}

\begin{abstract}
According to the Islamic faith, what happens in this world will not be limited to this world, unlike its react will be seen in the hereafter. It is stated in the Qur'ān that people will face various rewards or punishments in the hereafter according to their attitudes in this world. Accordingly, it is reported that one of the great rewards that will be given to those who live in this world as Allah wills and earn Paradise is the promise of peace in the hereafter. In the Qur'ān, some behaviors that will bring people's pleasure to Allah are also mentioned in praise or in another style. It is pointed out in the verses that demand peace to the owners of some behaviors that these behaviors are more lovable in the sight of Allah and have been said "Peace be upon him/them!". This situation includes to wishing of the peace in Qur'ān by statement as "Peace be upon him/them!" in absentia to some prophets or those who did some act. In the study, firstly, the word salām was analyzed with its lexical and term meanings, and then given information about the condition of the word salām in the Qur'ān. In the end determined those behavior which emitted in Qur'ān, by the word of "Peace be upon them/him!" and given some examples.

Keywords: Tafsīr, Qur’ān, Greeting, Soundness, Behaviour.
\end{abstract}

\section{Giriş}

Selâm kelimesi, selâmet, kurtuluş, maddi-manevi zararlardan ve musibetlerden uzak olmayı ifade eden bir terimdir. Müslümanlar, karşılaştıklarında aralarındaki sevgi, dostluk ve iyi niyet temennilerini bu terimle ifade ederler. Karşısındaki insanı "selâmün aleyküm" veya "es-selâmü aleyküm" şeklinde selâmlamak, "Selâm sizin üzerinize olsun! Her türlü belâ ve musibet sizden uzak olsun!" ifadesiyle muhatabın, canı, malı ve dini hususunda belâ ve musibetlerden uzak 
olabilmesi için dua ve temennide bulunmaktır. Buna göre "selâm" sözcüğü dinî ve dünyevî manada esenlik ve güvenlik anlamı taşımaktadır. ${ }^{1}$

Biriyle karşılaşıldığında yapılacak ilk hitap selâm vermektir. Bu manada toplumda tanışma ve kaynaşma onunla başlar. Selâm, mana itibariyle "Benden size asla kötülük dokunmaz." demektir ki böylelikle ortamda sevgi, güven ve emniyet hasıl olur. Diğer bir anlamıla selâm, "Size başkasından da zarar gelmesin!" manasında dilek ve temennide bulunmaktır. Bu şekilde insanlar birbirlerine iyilik dilemiş, sevgi ve yakınlığın en güzel temsilini göstermiş olurlar. ${ }^{2} \mathrm{Bu}$ duygu ve düşüncelerle iletişime başlandığında bireyler arasında karşılıklı kalbî yakınlık ve güven oluşur. Bu manada selamlaşma insanların karşılıklı olarak kaynaşmalarına ve sevgi beslemelerine katkı sağlayacaktır. ${ }^{3} \mathrm{Bu}$ nedenle olmalı ki İslâm âlimleri ahlâk konusunda, bireylerin toplum içerisinde birbirlerine karşı görevlerini sıralarlarken, selâmlaşmayı da ayrıca zikretmek suretiyle selâma önem vermişlerdir. ${ }^{4}$

Kur'ân'da, yabancı evlere hane halkından izin almadan ve onlara selâm verilmeden girilmemesinin emredilmesi, ${ }^{5}$ selâm verildiğinde daha güzeliyle veya aynıla mukabelede bulunulmasının istenmesi ${ }^{6}$ selâmın önemini vurgulamaktadır. Hz. Peygamber'in selâm alındığında daha güzeliyle mukabelede bulunmak için yapılan ziyadelere ayrıca sevap verileceğini ifade etmesi ${ }^{7}$ ve cennete girmeyi iman etmeye, iman etmeyi de birbirini sevmeye bağladığı hadislerinde, sevgi bağının ancak selâmlaşarak kurabileceğini haber vermesi, ${ }^{8}$ selâmın önemine işaret olarak değerlendirilebilir.

Kur'ân'da, selâm vermenin, bazı peygamberler tarafından kullanıldı̆̆ ${ }^{9}$ belirtilmektedir. Meleklerin insan suretinde Hz. Nûh ve Hz. İbrâhîm'e geldiklerinde; ${ }^{10}$ yine onların cennetliklere, ${ }^{11}$ hidayete erenlere $^{12}$ ve Allah'ın seçkin kullarına, ${ }^{13}$ cennetliklerinde birbirlerine ${ }^{14}$ selâm verdikleri haber verilmektedir. Ayrıca Allah Teâlâ'nın da iman eden kullarına ${ }^{15}$ ve peygamberlerine, ${ }^{16}$ onlar için övgü ve dua mahiyetinde, selâm verdiği ve Hz. Peygamber'e de iman eden kulları kendisine

Vecdi Akyüz, Kur'an'da Siyasi Kavramlar (İstanbul: Kitabevi Yayınları, 1998), 479-481.

Mâhir İz, Din ve Cemiyet (İstanbul: İrfan Yayınevi, 1973), 93.

Abdurrahman Kasapoğlu, "İslâm'da Selâm ve Selâmlaşma Olgusu”, Hikmet Yurdu Düşünce -

Yorum Sosyal Bilimler Araştırma Dergisi 3/6 (Temmuz-Aralık 2010), 52.

4 Muhammed Hamidullah, İslâm'a Giriș (Ankara: Nur Yayınları, ts.), 292; Muntasır Mîr, Kur'ânî

Terimler ve Kavramlar Sözlüğü, çev. Murat Çiftkaya (İstanbul: İnkılâb Yayınları, 1996), 171.

en-Nûr 24/27.

en-Nisâ 4/86.

Muhammed b. İsa et-Tirmizî, Sünenü't-Tirmizî, thk. Ahmed Muhammed Şakir (Beyrut: Dâru İhyâi't-Türâsi'l-'Arabiyye, ts.), "İsti'zân”, 2.

Bk. Ebu'l-Hüseyin el-Kușeyrî el-Müslim, Sahîh-u Müslim, thk. Muhammed Fuâd Abdülbâki

(Beyrut: Dâru İhyâi't-Türâsi'l-'Arabiyye, ts.), "İmân", 93.

Meryem 19/33, 47.

Hûd 11/48, 69; el-Hicr 15/52; ez-Zâriyât 51/25.

er-Ra'd 13/24; el-Hicr 15/46; en-Nahl 16/32; ez-Zümer 39/73; Kâf 50/34.

Tâhâ 20/47.

en-Neml 27/59.

Yûnus 10/10; İbrâhîm 14/23.

el-Ahzâb 33/44; Yâsîn 36/58.

es-Sâffât 37/79, 109, 120, 130, 181. 
geldiğinde onları selâm hitabıyla kabul etmesini emrettiği17 ${ }^{17}$ görülmektedir.

Kur'ân'a göre, selâm sözüyle karşılanma, cennette insana sunulacak en büyük mükâfatlardan biridir. Âyette sözü edilen selamlaşmanın keyfiyeti, belki dünya koşullarından farklı olsa da dünyada insanların birbirleriyle olan ilişkilerindeki selamlaşmaları hususunda eğitici mesajlar taşımaktadır. Ayrıca, Kur'ân’a göre selâm, ilk etapta insanlar arası ilişkilerde var olan bir kaide olarak ön plana çıssa da Allah Teâlâ'nın bazı insanları ve peygamberleri selamlamasıyla selâmın ilâhî alandan kopuk olmadığı da anlaşılmaktadır. Bu sayede birbirine selâm veren mü'minler, niyet ve düşüncelerini aynı zamanda Allah ile ilişkilendirme imkânı da bulmaktalar. ${ }^{18}$

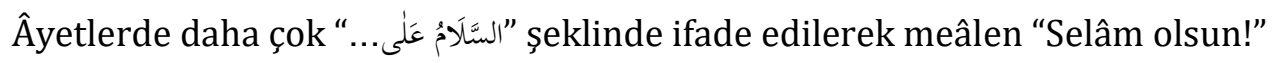
şeklinde çevrilen kısım, Türkçe'de "Saygım, esenlik dileklerim ulaşsın!"19 veya "Esenlik ve iyi dileklerim o kimse veya nesneye ulaşsın!" 20 anlamına gelen bir temenni sözüdür. Esenlik kelimesi ise genel anlamda "sağlık, sıhhat ve mutluluk içinde bulunma durumu, mutluluk, afiyet ve selâmet" olarak ifade edilebilir. ${ }^{21}$

Kur'ân'da Hz. Mûsâ ve kardeşi Hz. Hârûn, kendisini ilah ilan edecek kadar ileri giden $^{22}$ Firavun'la konuşmaya giderken onunla yumuşak sözlerle ${ }^{23}$ (kavl-i leyyin) diyalog kurmaları emredildikten sonra, devamında "Haydi, ona gidin de deyin ki: 'Biz, senin Rabbinin elçileriyiz. Ísrailoğullarını hemen bizimle birlikte gönder; onlara eziyet etme! Biz, senin Rabbinden bir âyet getirdik. Selâm, hidayete uyanlarındır.'"24 ifadeleri gelmektedir. Hz. Mûsâ ve Hz. Hârûn'a verilen tavsiyeler farklı yönleriyle ele alınmakla

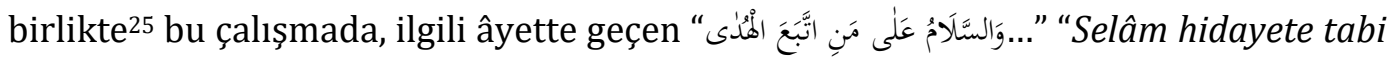
olanlaradır!"26 ifadesi spesifik bir davranıştan ziyade genel bir ifade olduğu için dışarıda bırakılmıştır. Buna göre çalışmada sabretmek, takvâ sahibi olmak, Allah'a asi olmamak, ana babaya iyi davranmak ve iyi işler yapmak gibi zihinde ve davranışta inşayı kolaylıkla hedefleyecek fiiller ele alınmaya çalışılmıştır. Bu manada çalışmanın amacı, esenlik dilenerek Kur'ân'da muhataplara örnek olarak sunulan numune davranışları belli başlıklar altında tasnif ederek tespit etmek, ilgili âyetler hakkında kaynaklarda bulunan rivayetleri ve yorumları tahlil etmektir.

Bir davranışı veya ismen zikredilen bir peygamberin esenlik dilenmesine vesile olan davranışını ön plana çıkarmayı hedefleyen bu çalışmada, ilk olarak selâm

el-En'âm 6/54.

Kasapoğlu, "İslâm'da Selâm ve Selâmlaşma Olgusu", 57.

bk. İsmail Parlatır vd., Türkçe Sözlük (Ankara: Türk Tarih Kurumu Basım Evi, 1998), 2/1934; Ali

Püsküllüoğlu, Türkçe Sözlük (İstanbul: Can Yayınları, 2008), 1511.

bk. Yașar Çağbayır, Ötüken Türkçe Sözlük (İstanbul: Ötüken Yayınları, 2007), 4/4129.

Şemseddin Sami, Kamus-ı Türkî (Ankara: Türk Dil Kurumu Yayınları, 2015), 318; Çağbayır,

Ötüken Türkçe Sözlük, 2/1481.

bk. eş-Şuarâ 26/23-29; el-Kasas 28/38; en-Nâziât 79/24.

Tâhâ $20 / 44$.

Tâhâ 20/47.

Örnek olarak bk. Ahmet Koç, "Dinî İletişim Bağlamında Kur'an'da "Kavl” (Söz) Çeşitleri”, Diyanet İlmi Dergi 43/4 (2008), 29-50. 
kelimesi sözlük ve terim anlamlarıyla tahlil edilecek, ardından, selâm kelimesinin Kur'ân'da geçme keyfiyeti hakkında bilgi verilecektir. Daha sonra ise Kur'ân'da, "selâm olsun!" denilmek suretiyle esenlik dilenmeye layık görülen davranışların tespit edilmesi adına, çalışmaya konu olan âyetler belli başlıklar altında ilgili hadis ve tefsir rivayetleri tahlil edilmek suretiyle değerlendirilecektir. Esenlik dileme manası içermeksizin, farklı anlamlarda kullanılan "selâm olsun!" ifadesini içeren âyetler ${ }^{27}$ çalışmanın dışında tutulacaktır.

\section{Selâm Kelimesinin Sözlük ve Terim Anlamları}

Arapçada "Selâm" (سلام) kelimesi kökü/sülâsîsi itibariyle "gizli ve açık tüm felaketlerden, hastalıklardan, kusurlardan, çirkin şeylerden uzak olmak, güvende olmak; kaza ve belâdan masûn ve berî olmak" gibi anlamlara gelen " "ـ" kökünden türemiş bir isimdir. ${ }^{28}$ Selâm kelimesi terim olarak "bir kimseye veya bir topluluğa yakınlık, sevgi ve nezaket göstermek, sağlık, başarı ve esenlik dilemek için 'selâmün aleyküm, merhaba, hayırlı işler' gibi sözlerden birini söylemek veya benzer dileklerin anlamını taşıyan bir işaret yahut harekette bulunmak" şeklinde ifade edilmektedir. ${ }^{29}$ Ayrıca selâm kelimesi esenleme, emniyet, sulh, asayiș, tahiyye gibi manalara da gelmektedir. ${ }^{30}$

Selâm kelimesi Allah Teâlâ'ya nispet edilerek "her türlü ayıp ve noksanlardan uzak bulunan, kullarını huzur ve selamete eriștiren" 31 ve "tüm eksiklik ve acziyetten, yaratılmışlara has değişikliklerden ve fanilikten münezzeh, selâmetin kaynağı olup esenlik veren"32 gibi manalara gelen O'nun isimlerinden olup, bu manada Kur'ân'da sadece bir yerde geçmektedir.33 Ayrıca "dâru's-selâm" (בَارُ السَّاَّم) ifadesi "barış ve esenlik yurdu" anlamında, sonu olmayan bir kurtuluş yurdu; hastalık ve ölümün ulaşamayacağı bir mekân ${ }^{34}$ olduğu için cennet ${ }^{35}$ hakkında kullanılmaktadır. Bu tabir, vaktiyle Bağdat şehrini ifade etmek için de kullanılmıştır. ${ }^{36}$ Allah'ın insanlara

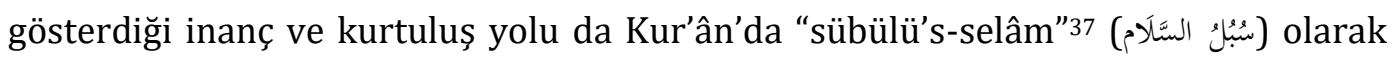

bk. el-A'râf 7/46; Hûd 11/69; İbrâhîm 14/23; en-Neml 19/59; el-Ahzâb 33/44; ez-Zuhruf 43/89; Vâkıa 56/91; Yâsîn 36/58; es-Sâffât 37/79, 104, 120, 130. bk. Ebû Abdirrahman Halil b. Ahmed el-Ferâhîdî, Kitâbu'l-'ayn, thk. Mehdî Mahzûmî - İbrahim Samraî (b.y.: y.y., ts.), "slm”, 7/265; Ebü'l-Fazl Muhammed b. Mükerrem b. Ali el-Ensârî İbn Manzûr, Lisânü'l-'Arab, thk. Abdullah Ali el-Kebîr vd. (Kahire: Dârü'l-Maârif, ts.), "slm", 24/20772078; Ebü'l-Feyz Murtaza Muhammed b. Muhammed b. Muhammed Zebîdî, Tâcu'l-'arûs min cevâhiri'l-kâmûs, (b.y.: Dâru'l-Hidâye, ts.), "slm”, 32/378-379. bk. İlhan Ayverdi, Misalli Türkçe Sözlük (İstanbul: Kubbealtı, 2011), "selam”, 3/2752.

Mehmet Bahaettin Toven, Yeni Türkçe Lügat (Ankara: Türk Dil Kurumu Yayınları, 2015)

"selam", 646; Çağbayır, Ötüken Türkçe Sözlük, "selam", 4/4129; Püsküllüoğlu, Türkçe Sözlük, "selam", 1511.

31 Ayverdi, Misalli Türkçe Sözlük, "selam", 3/2752-2753.

32 İbn Manzûr, "slm", 24/2078; Zebîdî, "slm", 32/378.

33 bk. el-Haşr 59/23.

34 İbn Manzûr, "slm", 24/2078.

35 el-En'âm 6/127; Yûnus 10/25.

36 bk. Toven, Yeni Türkçe Lügat, 646.

37 el-Mâide 5/16. 
ifade edilmiştir.

\section{Selâm Kelimesinin Kur'ân'da Geçme Keyfiyeti}

Kur'ân'de "selâm" kelimesi çeşitli isim ve fiil türevleriyle birlikte yüz elli yedi yerde geçmektedir. ${ }^{38}$ Bunlardan bazıları barıș,39 emniyet ve güven, ${ }^{40}$ esenlik, ${ }^{41}$ doğruya ve hidayete ulaşma ${ }^{42}$ gibi farklı anlamlara gelmektedir. Kelime "selâmün

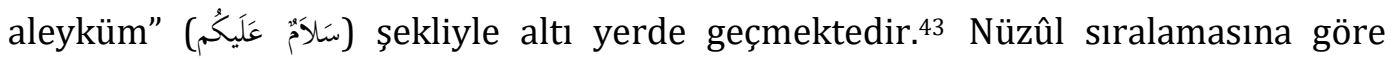
Kur'ân'da selâm kelimesi ilk olarak "O gece, fecrin doğuşuna kadar esenlik/selâmet doludur." 44 ifadesiyle geçmektedir. Ayrıca Kur'ân'ın başkaca yerlerinde de kelimenin esenlik/selâmet anlamlarında geçtiği görülmektedir. ${ }^{45}$

Meleklerin cennetlik mü'minleri karşılarken dört bir yandan gelip onlara, ahirette verilecek nimetlerin, dünyadaki sabırlarına karşıllk olarak verildiğini hatırlatarak "Selâm olsun size! Çünkü siz dünyadayken Allah yolunda çektiğiniz sikıntılara göğüs gerdiniz ve böylece mutlu sona eriştiniz. Dünya hayatının sonu (cennet) ne güzeldir!"46 sözleriyle karşılayacakları ifade edilmektedir.

Görevlerinden biri peygamberleri ve insanları müjdelemek olan meleklerden bazıları, insan șeklinde Hz. İbrâhîm'e gelmişler ve ona ileride âlim olacak bir evladını haber vermişlerdir. Bu olay Kur'ân'da anlatılırken, meleklerin söze selâm ederek başladıkları "Andolsun ki elçilerimiz (melekler) İbrâhîm'e müjde getirdiler ve 'Selâm' dediler. İbrâhîm de: 'Size de selâm olsun' dedi..."47 ifadeleriyle karşıllıklı selâmlaştıkları haber verilmektedir. Ayrıca Kur'ân'da, mü'minlere, Hz. Peygamber'e selâm etmeleri emredilirken "sellimû"48 (سَتِِّمُوا) ifadesi geçmektedir.

\section{Kur'ân'da “Selâm Olsun!” İfadesiyle Esenlik Dilenen Davranışlar}

Kur'ân-ı Kerîm, bir tarih, coğrafya kitabı veya vekâyi'nâme değil bir hidâyet rehberidir. Bu manada Kur'ân' da tarihi olaylar veya davranışlar aktarılırken, olayların iç yüzünün veya oluş şekillerinin araştırılmasının amaçlanmadı̆̆ı; bu olaylar hakkında niçin, nerede, ne zaman ve kim gibi soruların peşine düşülmediği görülmektedir. Buna göre Kur'ân'da çoğunlukla peygamberler dışında iyilerden ve isimlerden değil davranış kalıplarından bahsedilmektedir.

Bazı davranışların yerilip, yasaklanması gibi Kur'ân'da bazı olumlu

bk. Muhammed Fuâd Abdülbâkî, el-Mu'cemu'l-müfehres (Kahire: Dâru'l-Hadîs, 2001), "slm", 436-

439.

el-Furkân 25/63.

Tâhâ 20/47.

Yûnus $10 / 25$.

el-Mâide 5/16.

bk. el-En'âm 6/54; el-A'râf 7/46; er-Ra'd 13/24; en-Nahl 16/32; el-Kasas 28/55; ez-Zümer $39 / 73$.

Kadr 97/5.

bk. Hûd 11/48; el-Hicr 15/46; el-Enbiyâ 21/69; Kâf 50/34.

er-Ra'd 13/23-24.

Hûd 11/69.

el-Ahzâb 33/56. 
davranışlar da övülmek suretiyle evrensel niteliğe büründürülerek bu ilkelerin herkes tarafından benimsenmesi amaçlanmaktadır. Bu nedenle Kur'ân'da anlatılan olumlu bir davranışın faili, bizzat fiili yapan kendi çağının kimsesidir. Önemli olan o veya bu zamanda yaşamaktan ziyade, övülen o davranışların yapılıp yapılmadığıdır. Buradan hareketle çalışmanın bu başlığı altında, Allah Teâlâ tarafından Kur'ân-ı Kerîm'de, "Selâm olsun!" denilerek esenlik dilenmeye uygun görülen davranışların tespit edilmesi için temennilerin geçtiği âyetler içeriklerine göre farklı başlıklar altında tahlil edilecektir.

\subsection{Sabretmek}

Kur'ân'da, meleklerin dört bir yandan gelip mü'minlere, dünyadayken Allah yolunda çektikleri sıkıntılara olan sabırlarından dolayı cenneti hak ettiklerini selâm

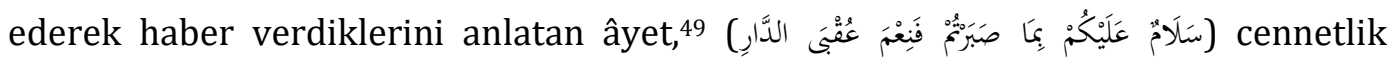
mü'minlere davranışları üzerinden esenlik dilenen durumlardan biridir. Burada

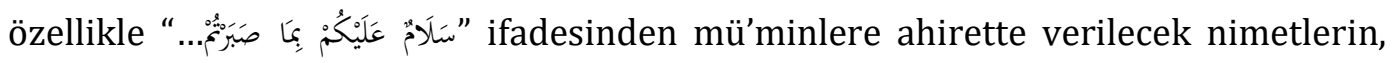
dünyadaki sabırlarına karşılık olarak verileceği anlaşılmaktadır.50 Buna göre Kur'ân'da melekler aracılı̆̆ıyla tebrik edilen mü'min davranışlarından birinin "sabırlı olmak" olduğu söylenebilir.

Sabır kelimesi Kur'ân'da, çeşitli isim ve fiil türevleriyle birlikte yüz üç yerde geçmektedir. ${ }^{11}$ Genel olarak Kur'ân'da sabırla ilgili, Allah'ın sabredenlerle beraber olduğu,52 sabrın peygamberlerin ahlâk1 ${ }^{53}$ ve yapılmaya değer işlerden ${ }^{54}$ olduğu, sabredenlerin amellerinin en güzeli ile ödüllendirileceği, 55 mükâfatlarının iki kez verileceği, ${ }^{56}$ sabreden toplumu yönetime getirmek için Allah'ın söz verdiğgi, ${ }^{57}$ kötülüğe karşılık iyilikle muamele de bulunarak aradaki düşmanlığı dostluğa çevirecek olgunluğun ancak sabredenlerde olduğu ${ }^{58}$ ve inananlara daima sabırlı olmanın emredildiği ${ }^{59}$ gibi ifadelerle bahsedilmektedir. Ayrıca, Kur'ân'da geçmemekle birlikte "çok sabırlı olan, günahkâr insanları cezalandırma konusunda acele etmeyerek onlara süre tanıyan" anlamlarına gelen "sabûr"60 (الصَبُور) ismi Allah Teâlâ'nın isimlerinden olarak sadece esmâ-i hüsnâ hadisinde geçmektedir.61

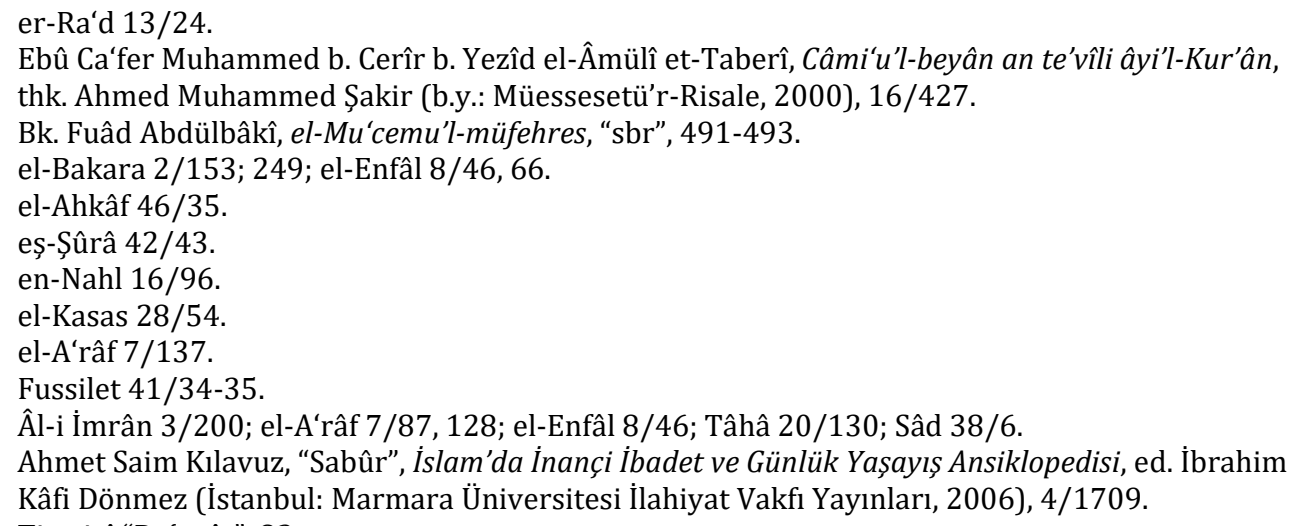


"Sabır" (صَبْ) kelimesi kökü/sülâsîsi itibariyle "hapsetmek, tutmak, engellemek, kendini veya bir başkasını bir şeyden alıkoymak, manen elini kolunu bağlamak, dirençli olmak, mukavemet göstermek" gibi anlamlara gelen "ص-ب-ر" kökünden türemiş bir isimdir. ${ }^{62}$ Terim olarak sabır, aklın ve şeriatın gerektirdiği şeylere karşı nefsi hapsetmek, kendini tutmak, ${ }^{63}$ dinin emir ve nehiylerini uygularken imtihan olan musibetlere karşı bıkkınlık göstermeden direnmek veya başa gelen musibetlere karşı direnç göstermek, her türlü olumsuzluğa karşı metanetli davranmaya devam etmektir. ${ }^{64}$

Yukarıda verilen tanıma göre sabır, sadece felaket ve musibetlere katlanmak değildir. Zira gerektiğinde bir sırrı saklamak, dili gereksiz şeyleri konuşmaktan korumak gibi farklı durumlar da sabır olarak ifade edilmektedir. ${ }^{65} \mathrm{Bu}$ manada bazı kaynaklarda sabrın, belâ ve musibetlere, ibadet ve taat üzere olmaya ve günahlara direnmek olmak üzere üç kısma ayrıldığı ifade edilmektedir.66

Sabır, genel bir ifadeyle, dünyada isabet eden musibetlerin ve sıkıntıların, yapılması gereken ibadetlerin ve sakınılması gereken haramların getirdiği meşakkat ve sıkıntılara karşı tahammül/direnç göstermek, bu hususlarda şeytana ve nefse değil, Allah'a ve Peygamberine tabi olmak olarak ifade edilebilir. Fakat burada Türk Dil Kurumu sözlüğünde "Acı, yoksulluk ve haksızlık gibi üzücü durumlar karşısında ses çıkarmadan onların geçmesini bekleme erdemi" 67 şeklinde tanımlanan sabrın, çalışmamıza konu olan sabırdan çok farklı olduğu ifade edilmelidir. Buna göre yukarıdaki ifadelerle bu tanım değerlendirildiğinde, bunun eksik bir tanım olduğu söylenmelidir. Çünkü sabır, tabiri caizse eli-kolu bağlı bir şekilde edilgen bir bekleyișten ziyade, gelișen olay ve durumlara karşı aktif bir gayreti ve direnç göstermeyi ifade etmektedir.

Sabır kelimesinin manasında, son derece zorlu şartların hüküm sürdüğü çölde, herkesin kendi yaşamını kazanmak için olağanüstü sabır ve dayanıklılık göstermesi gereken maddi gücü ve ne olursa olsun devam etmesi gereken bir kararlılı̆̆ ifade ederken, Kur'ân, bu eski göçebe erdemini, kendisine belli bir yön vermek suretiyle dinin en önemli erdemlerinden biri haline yani Allah yolunda sabra

62 İbn Manzûr, “sbr”, 27/2381-2382; Zebîdî, Tâcu'l-'arûs, "sbr”, 12/271-273; Eyyûb b. Mûsâ elHüseynî Ebü'l-Bekâ el-Kefevî, el-Külliyyât, thk. 'Adnan Dervîș - Muhammed el-Mısrî (Beyrut: Müessesetü'r-Risale, 1998) "sbr", 560; Ebu'l-Kâsım Hüseyin b. Muhammed b. Mufaddal Râgıb elİsfahânî, el-Müfredât fí garîbi'l-Kur'ân, thk. Muhammed Halil Aytânî (Beyrut: Dâru'l-Mârife, 2005), "sbr", 277.

63 Râgıb el-İ̀sfahânî, el-Müfredât, "sbr", 277.

64 Mustafa Çă̆rıcı, "Sabır”, Türkiye Diyanet Vakfi İslâm Ansiklopedisi (İstanbul: Türkiye Diyanet Vakfı Yayınları, 2008), 35/337.

65 Farklı tanımlar için bk. Ebû Abdullah Fahreddîn er-Râzî, Mefâtîhu'l-gayb (Beyrut: Dâru'lKütübi'l-'İlmiyye, 2000), 3/46-47; Elmalılı Muhammed Hamdi Yazır, Hak Dini Kur'ân Dili (İstanbul: Eser Neşriyat ve Dağıtım, 1979), 1/544-546; Ebu'l-A'lâ el-Mevdûdî, Tefhîmu'l-Kur'ân, çev. Muhammed Han Kayani vd. (İstanbul: İnsan Yayınları, 2006), 1/73; İsmail Karagöz, "Kur'an ve Hadislerin Ișığında Sabır ve İnsan", Diyanet İlmi Dergi, 38/1 (2002), 6. 
dönüştürmüştür. Bu manasıyla sabır kelimesi ilk olarak, cahiliye günlerinde olduğu gibi savaş alanında mü'minlerin bir vasfı olarak zikredilmiştir. ${ }^{68}$ Daha sonra ise kelime takvâ ile ilişkilendirilerek sabredilmesi sonucunda kazananların müttakiler olacağı ifade edilmiştir. ${ }^{69}$ En nihayetinde ise sabır kelimesi Allah'a tam bir şekilde inanmanın asli boyutunu temsil eder niteliğe kavuşturulmuştur. ${ }^{70} \mathrm{Bu}$ manada sabır, Allah'a inanmanın asıl boyutunu göstermesi açısından önemlidir ki bu durum iman olumsuz şartlar altında kaldığında kendini göstermektedir. ${ }^{71}$

Yukarıda geçen âyette, "Sabrettiğiniz șeylere karşılık sizlere selâm olsun!" ifadesi geçerken, "diyeceklerdir" sözü zikredilmemiştir. Bu yönüyle burada hazf vardır, takdiri de "Melekler onların yanına her kapıdan gelirler ve 'Selâmün aleyküm' derler" şeklindedir. Yani burada meleklerin cennetlikleri bu ifadelerle karşılayacakları âyetteki tasvirden anlaşıldığı için "derler" ifadesi hazfedilmiştir. Bu durumun sonucu olarak, selâm olsun ifadesinin "Selâm sizlere ise artık sizler her türlü üzüntü ve kederden esenliktesiniz." manasına geldiği belirtilmektedir. Ayrıca bu ifadenin esenlik durumlarının devam etmesi için onlara yapılan bir dua olduğu da belirtilmiştir. Bu durumda, âyetin ifadesi haber kipi olmakla birlikte mana olarak içeriğinde dua anlamı taşıdığı anlaşılmaktadır.72

Zikri geçen âyetteki "Sabrettiğiniz şeylere karşılık..." ifadesiyle ilgili, birincisi, selâm merkezli ve "Bu selâm, tâatlara ve haramları terk etmeye olan sabrınız sayesinde sizin için tahakkuk etmiştir." anlamında; ikincisi, verilen nimetler merkezli ve "Sizlere sunulan bu ikramlar ve gördüğünüz hayırlar, sabrınız sebebiyle tahakkuk etmiştir." manasında olmak üzere iki farklı yorum yapılmıștır. ${ }^{73}$ Buna göre yorumların biri söylenen ifadeye diğeri ise neye mukâbil söylendiği olmak üzere iki farklı anlam içeriğinin bulunabileceği anlaşılmaktadır.

Selâm ifadesinin geçtiği ilgili âyet Ra'd 24 olmakla birlikte, 20-24. âyetler arasında zikredilen, Allah'a verilen sözü tutmak, ${ }^{74}$ O'nun gözetilmesini emrettiği hususları gözetmek,75 O'nun rızasına ermek için sabretmek, namazı dosdoğru kılmak, kendilerine verilen rızıktan gizli-açık infak etmek, kötülüğü iyilikle savmak ${ }^{76}$ gibi amelleri yerine getirmek da aslında bir sabır işidir. Ve 23. âyette bu durumları sabrederek yaşayan mü'minlerin cennette melekler tarafından karşılanacağı haber verilmektedir. Buna göre yukarıda sıralanan amelleri hayata geçirmenin bir sabır işi, bu sabrın karşılığının da 'adn cennetleri ve orada meleklerin selâmlamalarına

el-Bakara 2/249-250; Âl-i İmrân 3/146.

el-A'râf $7 / 128$.

bk. el-En'âm 6/34; el-Mü'minûn 23/109-111; el-Müzzemmil 73/10-11.

Toshihiko İzutsu, Kur'an'da Dînî ve Ahlâkî Kavramlar, çev. Selahattin Ayaz (İstanbul: Pınar Yayınları, 2013), 179.

72 Ebû Abdullah Muhammed b. Ahmed b. Ebî Bekr el-Kurtubî, el-Câmi' li ahkâmi'l-Kur'ân, thk. Ahmed el-Berdûnî - İbrahim Etfıyyiş (Kahire: Dâru'l-Kütübi'l-Mısriyye, 1964), 9/312; Râzî, Mefâtîhu'l-gayb, 19/36-37.

73 Râzî, Mefâtîhu'l-gayb, 19/36-37.

74 er-Ra'd $13 / 20$.

75 er-Ra'd $13 / 21$

76 er-Ra'd $13 / 22$ 
muhatap olmak olduğu anlaşılmaktadır.

Kur'ân'da “Andolsun ki sizi biraz korku ve açlık; mallardan, canlardan ve ürünlerden biraz azaltma (fakirlik) ile deneriz. (Ey Peygamber!) Sabredenleri müjdele!"77 şeklinde geçen ifadeyle kulların dünyada zaman zaman imtihana tabi olacaklarını, buna karşı sabır göstermeyenlerin imtihanı kaybederken sabredenlerin ise ilahî müjdeye nâil olacakları haber verilmektedir. Yine peygamberlerden bahseden bazı âyetlere bakıldığında, hastalıklarla boğuşarak imtihana tabi olmuş ve sabrederek kazanmış sabır timsali olan Hz. Eyyûb'un “...Gerçekten biz Eyyûb’u sabırlı (bir kul) bulmuştuk. $O$, ne iyi kuldu!..."78 ifadeleriyle övüldüğü görülmektedir.

Tebliğ hayatı boyunca karşılaştığı tüm sıkıntılara karşı Hz. Peygamber'i her konuda farklı âyetlerle destekleyen Allah Teâlâ, sabır konusunda "O halde (Resûlum), peygamberlerden azim sahibi olanların sabrettiği gibi sen de sabret!..."79 ifadesiyle yine desteklemiş ve O'na daima sabırlı olmasını emretmiștir. Bu minvalde Hz. Peygamber de "Mü'minin hâli ne güzeldir! Her hâli kendisi için hayırlıdır ve bu durum sadece mü'mine hastır. Çünkü onun başına güzel bir hal geldiğinde şükreder; bu, onun için hayırlıdır. Başına bir musibet geldiğinde ise sabreder; bu da onun için hayırlıdır." 80 şeklinde mü'min tanımı yaparak, bolluk ve darlık anında sabırlı olmanın mü'minlerin özelliklerinden biri olduğuna vurgu yapmıştır.

Sabır hakkında, "Hiç kimseye sabırdan daha hayırlı ve geniş bir nimet verilmemiştir." ${ }^{11}$ şeklinde buyuran Hz. Peygamberle çocuğunu kaybeden bir kadın arasında cereyan eden bir hadise nakledilmektedir: Hz. Peygamber, (çocuğunun) mezarı başında feryat figan ağlayan bir kadına rastlamış ve ona "Allah'tan kork ve sabret!" buyurmuştur. Kadın ise kendisini uyaranın Hz. Peygamber olduğunu bilememiş, "Git başımdan! Çünkü başıma gelen musibet, senin başına gelmemiştir." diye cevap vermiştir. Daha sonra, konuştuğu kişinin Peygamber olduğunu öğrendiğinde, Hz. Peygamber'in kapısına gitmiş, özür beyanı sadedinde sözler söylemiştir. Bunun üzerine Hz. Peygamber, "Sabır, felâketle karşılaştığın ilk anda dayanmakla olur." șeklinde buyurmuştur." 82

Yukarıda zikredilen hadisede, insana verilen unutma nimeti nedeniyle başa gelen nice dert ve sıkıntıların zaman geçtikçe unutulduğu ve acının da azaldığı düşünüldüğünde, inananların herhangi bir musibetle karşılaştıkları ilk anda o olaya karşı sabırla direnç göstermelerinin ve imtihan olduğunu akıllarından çıkarmadan katlanmalarının önemine vurgu yapıldığı görülmektedir. Buna göre sabrı edinmekteki en önemli rolün, karşılaşllan üzücü bir durumun meydana getirdiği manevi sadmeye karşı, ilk anda ortaya konulan tahammül olduğu anlaşılmaktadır.

bk. el-Bakara 2/155.

Sâd 38/44.

el-Ahkâf 46/35.

Müslim, "Zühd", 64.

Ebû 'Abdullâh Muhammed b. İsmâil el-Buhârî, Sahîhu'l-Buhârî, thk. Mustafa Dîb el-Buğa (Beyrut: Dâru İbn Kesîr, 1987), "Rikâk", 20; Müslim, "Zekât", 124.

82 bk. Buhârî, "Cenâiz", 31, 32; "Ahkâm”, 11; Müslim, “Cenâiz", 15. 
Hayatta karşılaşılan bazı sıkıntılı süreçler kulun iradesini aşabilmektedir. Böyle zamanlarda şikâyet etmeden ilahi takdiri kabullenerek sebat göstermek mü'minlerin özelliklerindendir. Bu manada Kur'ân'da, karşılaşılan sıkıntılara ve musibetlere karşı başkasına şikâyet etmeden, onlara tahammül göstermek demek olan güzel sabır (sabr-ı cemil) tavsiye edilmektedir. ${ }^{83}$ İnananların sıkıntı ve kederlere karşı sabretmesi gerektiği gibi rahat imkanlara sahip olduklarında da dini ölçü ve kuralları aşmama hususunda da sabretmeleri gerekmektedir.

Netice olarak, Ra'd sûresi 20-23 âyetleri arasında hem sosyal ahlâka hem de Allah Teâlâ ile olan ilişkilere ışı tutularak mü'minlerin sergiledikleri sabrın karşılığının 'adn cenneti olacağı ifade edilmektedir. Bu âyetler grubundaki davranışları sergilerken, katlanılan sabrın bir neticesi olarak da 24. âyette cennette meleklerin "selâm" ifadesiyle tebrikleri belirtilmektedir. Buna göre, sabır davranışı başta olmak üzere, dünyadaki tüm durumlara karşı sabrederek Allah’a verdiği sözü tutmanın, O'nun gözetilmesini emrettiği hususları gözetmenin, O'nun rızasına ermek için her zaman sabretmenin, namazı dosdoğru kılmanın, kendilerine verilen rızıktan gizli-açık infak etmenin ve kötülüğe karşı iyilik yapmanın, Allah katında sonucu melekler tarafından tebrik ve esenlik dilenerek karşılanmayı hak eden davranışlardan olduğu anlaşılmaktadır.

\subsection{Takvâ Sahibi Olmak}

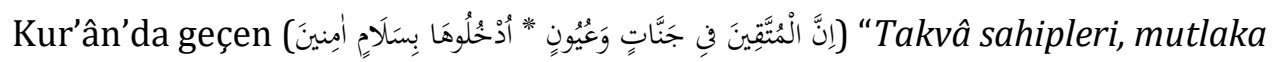
cennetlerde ve pınar başlarında olacaklar. (Onlara) 'Oraya emniyet ve selâmetle girin' (denilir)." 84 meâlindeki âyette takvâ sahiplerinin cennete girecekleri ve orada selâm ile karşılanacakları ifade edilmektedir. Ayrıca, cennete grup grup sevk edilecek müttakilerin cennet bekçileri tarafından “...Selâm size! Hoş geldiniz! Ebedî olarak kalmak üzere girin cennete!"85 ifadesiyle selâm ifadesiyle karşılanacakları haber verilmektedir. Buna göre cennette görevli meleklerin oraya gelenlere söyledikleri övgü dolu güzel sözler ve akabinde cennetliklerin, rablerine karşı şükran ve minnetlerini belirten sevinç dolu ifadeleri de ${ }^{86}$ inananları, takvâlı yaşamaya, bu manada Allah Teâlâ'nın hoşnutluğunu kazanmak için faydalı işler yapmaya teşvik etmektedir.

“Takvâ" (التَّقوُىى) kelimesi kökü itibariyle "himaye etmek, korumak, sakınmak, örtmek, bir şeyi ona rahatsızlık verecek, eziyet edecek şeylerden korumak, kollamak ve muhafaza etmek" gibi anlamlara gelen "و-قي" (v-k-y) kökünden türemiş bir isimdir. Terim olarak ise genel bir ifadeyle "Allah'ın emirlerine uymak, yasaklarından da kaçınmak suretiyle korunmak, bu konuda titizlik göstermek.” şeklinde

Yûsuf $12 / 18$.

el-Hicr 15/45-46.

ez-Zümer 39/73.

İlgili âyetin devamında cennete giren müttakilerin memnuniyetlerini "Bize verdiği sözü yerine getiren ve cennetten bize dilediğimiz yerinde mesken kurabileceğimiz yurt bağıșlayan Allah'a hamdolsun!" sözleriyle belirtecekleri ifade edilmektedir. Bk. ez-Zümer 39/74. 
tanımlanabilir. Kavramın içeriğinde korku manası bulunmakla birlikte bu durum vahşi bir varlıktan korkmayı değil aksine seven bir kimsenin sevdiğini üzmekten çekinmesini, bu manada kendisini yaratanına karşı sorumluluk ve saygı duyarlılığını barındırmaktadır. Bu bağlamda takvâ, Allah'a duyulan saygı ve hürmet kaynaklı "Allah bilinci veya Allah'a karşı sorumluluk bilinci" şeklinde anlaşılabilir. Çünkü buradaki korkunun kaynağı Allah'a duyulan sevgi ve saygıdır. Bu nedenle bu bilinç, inananları türlü kötülüklerden ve günahlardan uzak tutarak, iyi ve güzel olana yönlendiren bir şuur olarak ifade edilmektedir. ${ }^{87}$

Yukarıda verilen bilgileri destekler mahiyette, kaynaklarda, takvâ kelimesinin cahiliye döneminde maddi bir tehlikeden korunma olarak, -hayvan olsun insan olsuncanlıların dışarıdan gelebilecek tehlikelere karşı kendilerini savunması manasında kullanılırken; Kur'ân'ın kelimeye temel anlamını da yanında taşıyarak herhangi bir şeyden değil, insanı Allah'ın azabına sürükleyecek olan mâsiyetten korunma manası yüklediği belirtilmektedir. ${ }^{88}$ Buna göre mana, insanın kendisini Allah'ın korunmasına koymak suretiyle, ahirette elem ve azaba neden olacak durumlardan titizlikle koruması yani günahlardan geri durup, sevaplara sarılması olarak ifade edilmiştir. ${ }^{89}$ Dolayısıyla takvâ kavramına, asıl lügat manasını yitirmemekle birlikte, Kur'ân'da daha çok mânevî alanda önemli bir anlam yüklendiği ${ }^{90}$ ve Kur'ân'ın dünya görüşünün oluşumunda hayati rol oynayan önemli kelimelerden biri olduğu anlaşılmaktadır. ${ }^{91}$ Bu manada takvâ sahibi kimselerin, Kur'ân'da, Rablerini görmedikleri/kendi başlarına kaldıkları halde ondan sakınarak yaşadıkları ifade edilmektedir.92

Yukarıdaki tanımlar değerlendirildiğinde Allah'tan tam manasıyla sakınan bireyin kimseye zarar veremeyeceği, bu duygu ve inançla, devamlı olarak, O'nun sevdiği ve razı olduğu şeyleri gözeteceği ifade edilebilir. Bu durum da insanın vicdanının hâkim olduğu, kötülüklerden ve suçlardan uzak yaşanan bir hayatı yaşaması demektir. ${ }^{93}$ Allah'ın emir ve yasaklarına itaat etmenin yanında ayrıca Hz. Peygamber tarafından, haram veya helalliği şüpheli olan şeylerden kaçınma da takvânın bir gereği olarak ifade edilmiştir. ${ }^{94} \mathrm{~Hz}$. Peygamber ayrıca "Nerede olursan ol, takvâ sahibi ol!"95 şeklinde buyurmak suretiyle takvalı olmayı emretmiş; kendisine insanı cennete en çok götürenin ne olduğu sorusunu da "Takvâ ve güzel ahlâk" diye cevaplamıştır. ${ }^{96}$

bk. Ferâhîlî, Kitâbu'l-'ayn, "vky", 5/238-239; İbn Manzûr, "vky", 51/4901-4902; Zebîdî, Tâcu'l'arûs, "vky", 40/226-231; Ebü'l-Bekâ el-Kefevî, el-Külliyyât, 299; Râgib el-İsfahânî, el-Müfredât, "vky", 545-546.

bk. Toshihiko İzutsu, Kur'an'da Tanrı ve Insan, çev. M. Kürşad Atalar (İstanbul: Pınar Yayınları, 2012), 42-43, 345; Süleyman Ateș, Kurân-ı Kerîm Tefsiri (b.y.: Bilmar Yayıncılık, ts.), 1/91. Yazır, Hak Dini Kur'ân Dili, 1/169. İsmail Karagöz, "Kur'an'da Takvâ Kavramı ve Muttakî İnsanın Özellikleri", Diyanet İlmi Dergi, 31/4 (1995), 51.

İzutsu, Kur'an'da Tanrı ve İnsan, 345-352.

el-Enbiyâ 21/49.

Ali Ünal, Kur'an'da Temel Kavramlar (İstanbul: Beyan Yayınları, 1990), 512-513.

Müslim, "Müsâkât", 107.

Tirmizî, Birr, 55.

Tirmiz, Birr, 62. 
Selâm ifadesiyle övülmenin haricinde Kur'ân'da takvâ sahiplerinden devamlı olarak övgüyle bahsedilmektedir. Buna göre Allah Teâlâ'nın müttakilerin dostu olduğu, ${ }^{97}$ onlarla beraber olduğu, ${ }^{98}$ onları sevdiği, ${ }^{99}$ sabırlı olmaları halinde onları kötü niyetli kimselerin tuzak ve desiselerinden koruyacağ ${ }_{1}{ }^{100}$ yerin ve göğün bereket kapılarının onlara açılacağl, ${ }^{101}$ mutlu sonlarının olacağl ${ }^{102}$ cennete ve her türlü nimetlere sahip olacaklar1 ${ }^{103}$ ve güvenli bir makamda oldukları ${ }^{104}$ gibi ifadelerle yer verilmektedir. Ayrıca Kur'ân'da “Şüphesiz ki Allah katında en klymetli olanınız en takvâlı olanınızdır."105 ifadesiyle de Allah nezdindeki kiymetin ölçütünün zenginlik, soy, güzellik, makam ve mevki vb. değil, takvâ olduğuna işaret edilerek insanın takvâsı oranında Allah katında değer kazandığı ifade edilmektedir.

Kulun, Rabbi katındaki kıymetinin ölçüsü, O’nun emirlerine uyma ve yasaklarından kaçınma hususunda gösterdiği hassasiyete göre değerlendirilir. Böyle bir duyarlılığa sahip olmak da zaten kişiyi kötülüklerden vazgeçirmek suretiyle iyiliğe sevk edecektir. Bu sebeple olmalıdır ki Kur'ân'da Allah'ın müttakilerle beraber olduğu, ${ }^{106}$ onların dostu olduğ ${ }^{107}$ ve onlara korku ve hüznün olmayacağ ${ }^{108}$ haber verilmektedir. Ayrıca Hz. Peygamber'in devamlı olarak "Allah'ım nefsime takvâsını ver ve onu temizle..." 109 şeklinde dua etmesi ve yolculuğu çıkacakken kendisine dua etmesini talep eden bir sahâbîye de "Allah, seni takvâ ile azıklandırsın!" şeklinde dua etmesi, takvâ ahlâkının önemine işareti yönüyle değerlidir.

Kur'ân'da, takvâ hususunda kimin ne kadar takvâ sahibi olduğunun bilgisinin Allah'a ait olduğu haber verilirken,110 insanın ahlâkî anlamda kusur, ayıp ve eksikliklerini örterek onu güzelleştirecek olan şeyin de "takvâ elbisesi" (لِبَاسُ التَّقْونى) olduğu, "Ey Âdemoğulları! Size mahrem yerlerinizi örtecek giysi, süslenecek elbise yarattık. Takvâ elbisesi, işte o daha hayırlıdır..."111 ifadeleriyle haber verilmektedir. Âyette geçen "takvâ elbisesi", bazı tefsirlerde "bedeni örten elbise, miğfer ve zırh gibi savaş klyafetleri; mecazi anlamda ise salih amel, namus ve tevhid" gibi tabirlerle açıklanmakla birlikte, ${ }^{112}$ aslında ilgili âyette takvânın "hayâ" ile olan münasebeti gösterilmek suretiyle, dolaylı bir üslûpla, takvânın, günah hislerini örterek engelleyen, böylelikle günah işlemeye mani olan koruyucu bir erdem olarak ifade

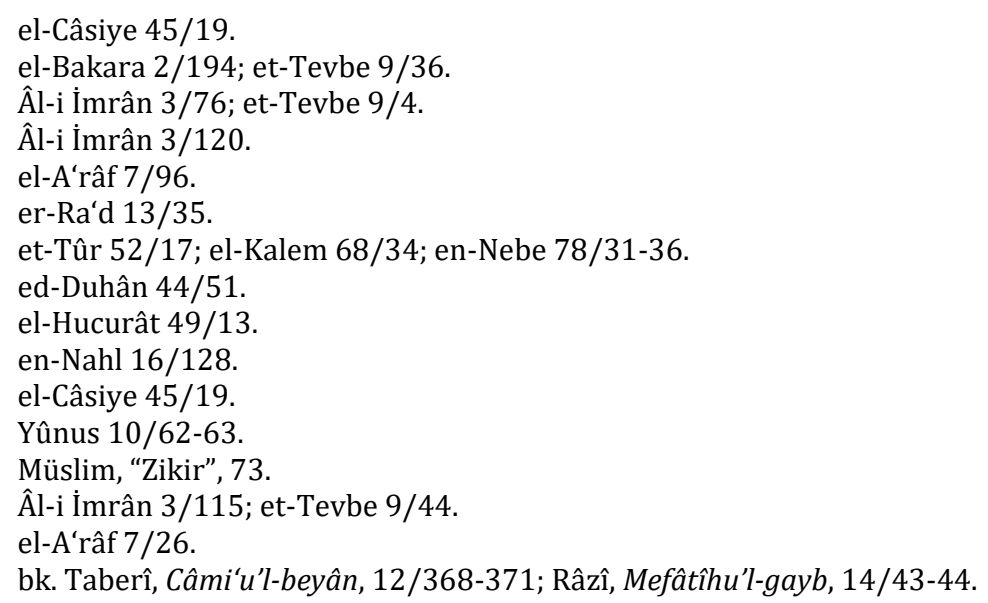


edilmektedir.113 Yani bir elbisenin insan bedenini kapatıp, koruması ve güzelleştirmesi gibi takvâ ahlâkı da manevi anlamda ruhu, kötü duygu ve düşüncelerden korumakta ve güzel davranışlarla bezemektedir.

Allah Teâlâ'nın selâm ederek tebrik ve esenlik dilediği müttakilerin kapsamıyla ilgili genel anlamda iki farklı görüş ifade edilmektedir. Birinci görüşe göre müttaki ifadesi, bir övgü ismi olduğundan her türlü günah ve isyandan ittikâ edenler kastedilmiştir. İkinci görüş ise sahabe ve tabiînin çoğunun ittifak ettiği Allah'a eş koşmaktan ve O’nu inkâr etmekten kaçınan kimselerin kastedilmiş olduğu görüşüdür. ${ }^{114}$ Kanaatimizce ve yukarıda yapılan tanımlar da göz önünde bulundurulduğunda, sakınmanın devamlı surette olmasının gerekliliği anlaşılmaktadır. Sakınılan hususların da Kur'ân ve sünnette bir kereliğine yasaklanmamış olması hasebiyle, ilgili âyette Mevdûdî'nin (ö. 1903-1979), müttaki tanımında da ifade ettiği şekliyle, ömrünü Allah'a itaatle geçiren kimselerin ifade edildiği söylenebilir. ${ }^{115}$

İlgili âyetler bağlamında Kur'ân'da takvânın üç mertebeyle ele alındığından bahsedilebilir. ${ }^{116}$ Buna göre ilki, şirkten sakınmak suretiyle sadece Allah'a inanarak sonsuz bir azaptan kurtulmak; ${ }^{117}$ ikincisi, emirleri yerine getirmek suretiyle büyük olsun küçük olsun tüm günahlardan sakınmak; ${ }^{118}$ üçüncüsü ise gönlü Allah Teâlâ'nın sevgisinden uzaklaştıran her şeyden temizleyerek, tam anlamıyla O'na yönelerek bağlanmaktır. ${ }^{119}$ Müfessir Râzî (ö. 606/1210) ise bu sayıyı çoğaltarak takvâ kelimesinin Kur'ân'da, iman, ${ }^{120}$ tevbe, $^{121}$ itaat, ${ }^{122}$ günahı terk etme ${ }^{123}$ ve ihlas ${ }^{124}$ anlamlarında olmak üzere beş farklı manada kullanıldığını belirtmektedir. ${ }^{125}$

Yukarıda zikredilen mertebeler, müttakilerle kimlerin kastedildiğiyle ilgili farklı görüşlerin ortasını bulma anlamında da değerlendirilebilir. Çünkü bu mertebelere bakıldığında hem birinci görüşün sahiplerinin ifade ettiği durumu hem de ikinci görüşün sahiplerinin söylediklerini kapsadığı görülmektedir. Buna göre bazı tefsir kaynaklarında, Allah ve elçisine itaat eden, haram ve yasaklardan sakınan, bu manada helal-haram sınırlarını koruyan, üzerine düşen farzları yerine getiren, Allah'ın rahmetini umarak azabından da çekinerek O'na karşı gelmekten sakınanlar olarak tanımlanan müttakiler için şu üç şarttan bahsedilmektedir: 1) Allah'a iman

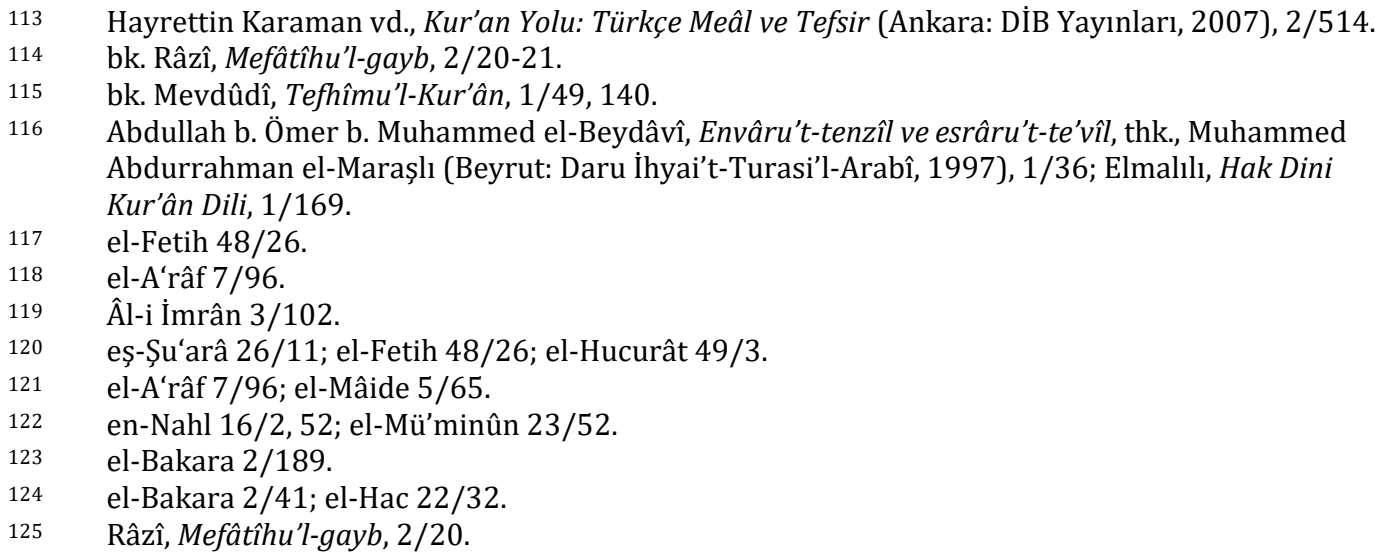


edip şirkten, küfür ve nifaktan sakınmak. 2) Allah ve peygamberine itaat ederek onların emrettikleri şeyleri yapmak. 3) Onların yasakladıkları fiilleri ve haramları terk etmek, dünya ve ahirette nefsine zarar verecek şeyleri yapmaktan sakınmak. ${ }^{126}$

Buraya kadar yer verilen ifadelere bakıldığında aslında "muttaki" ifadesiyle, Allah'a iman eden ve inancının gereğini yerine getiren mü'minlerin kastedildiği ifade edilebilir. Bu manada her mü'mine, bu özelliği taşımak şartıyla, müttaki denilebilir. Fakat bunlar arasında derece farkı vardır. İnanan mü'min inandığı değerlere ne kadar bağlı bir şekilde kurallara uyarsa, takvâ derecesinin de o kadar olduğu söylenebilir. İlgili âyetlerde kastedilen takvâ sahiplerinin ise dünyada iken güçleri nispetinde Allah'ın koymuş olduğu sınırlara itaat ederek yaşayamaya çalışanlar olduğu muhakkaktır.

Netice itibariyle, inanan bireylerin her zaman ve zeminde davranışlarının ilahi iradeye uygun düşüp düşmediğini sorgulaması durumu takvâ olarak ifade edilebilir. Buna göre Kur'ân'da “...Allah katında en değerli olanınız, O'ndan en çok korkanınızdır..."127 şeklindeki ifadeyle insanoğlu için tek değer ölçüsü olarak vurgulanan takvâ, psikolojik olarak korkmaktan ziyade, Allah'a karşı derin bir saygı duymayı, her davranışta O’nun rızasının kaygısını taşımayı, O’nun hoşnutluğunu kaybettirecek her türlü davranıștan uzak olmayı ifade etmektedir. Bu durumu yerine getirirken de nefsin ve şeytanın her türlü olumsuz engeline rağmen, bu engele karşı direnç gösteren takvâ sahiplerine, Allah Teâlâ'nın övgüsü ve ödülü olarak da selâm ifadesiyle karşılanarak esenlik dilenecekleri anlaşılmaktadır.

\subsection{Allah'a Asi Olmamak ve Anne-Babaya Güzel Davranmak}

Kur'ân'da “(O,) Ana babasına çok iyi davranırdl; o, isyankâr bir zorba değildi. Doğduğu gün, öleceği gün ve diri olarak kabirden kaldırılacağı gün ona selâm olsun!"128

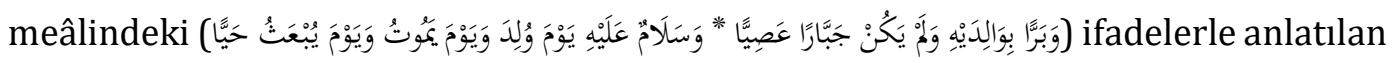
Hz. Yahyâ'nın güzel hasletleri sebebiyle, Allah Teâlâ'nın övgüsüne mazhar olduğu ve selâm temennisiyle anıldı̆̆ı görülmektedir. Âyette ayrıca, dünyaya gelirken, dünyadan göçerken ve tekrar dirilme gününde Allah'ın yardımının da onunla olacağı bildirilmiştir. Çalışmanın bu başlığında Hz. Yahyâ'nın Allah Teâlâ'dan selâm tebriğini almasının büyük ölçüde nedeni olduğu anlaşılan davranışlardan Allah'a karşı asi olmamak (itaatkâr olmak) ve ana babaya iyi davranmak üzerinde durulacaktır.

Âyette geçen "berr" (بََّّ) kelimesi, "doğru olmak, yeminine bağlı olmak, itaat etmek" anlamlarına gelmektedir. ${ }^{129}$ Burada ismi fâil manasında "bâr" (بَّر) veya "mütî"” (مُطِيعًا) manasında olduğu ifade edilmektedir ki buna göre mana "itaat edip iyilik yapan, ihsan eyleyen" şeklindedir. Ayrıca benzer bir ifadenin başka bir âyette "Rabbin,

126 bk. Taberî, Câmi'u'l-beyân, 232/233.

127 el-Hucurât 49/13.

128 Meryem 19/14-15.

129 Râgıb el-İsfahânî, "brr", 51. 


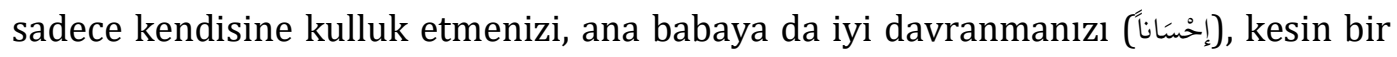
şekilde emretti." 130 şeklinde geçmesi de bu manayı desteklemektedir. ${ }^{131}$ Ayrıca tefsir

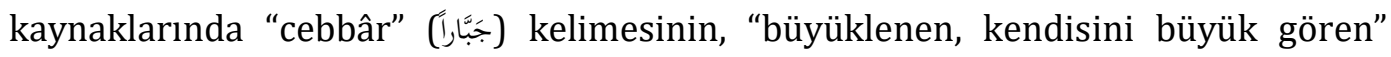

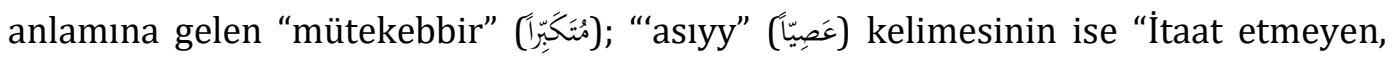
Allah'ın emrine veya ana babaya karşı gelen"132 manalarına gelen “âsîy” (عَاصِي) şeklinde olduğu ifade edilmektedir.133 Âyette geçen (وَمَ...) “...ve lem yekûn cebbâran"134 ifadesinin bazı tefsir kaynaklarında, "O, çok öldüren değildi." manasında olduğu söylenerek Hz. Yahyâ'nın "Öfkelenip öldüren ve öfkesine kapılıp başkasına vuran biri değildi." anlamında olduğu belirtilse de ${ }^{135}$ yukarıda önce verilen manaların daha münasip olabileceği düşünülmektedir.

Yukarıda verilen bilgiler göz önünde bulundurulduğunda ilgili âyette, ism-i fâil kalıbıyla mana verilen kelimelerle, Hz. Yahyâ'nın, Allah'ın emir ve yasaklarına karşı gelmemek ve ana babaya iyi davranmak gibi iki güzel davranışından bahsedildiği anlaşılmaktadır. Bu hasletlerin zikrinden sonra gelen "ve selâmün aleyhi" ifadesi de Allah Teâlâ'nın, üzerinde bulundurduğu hasletlerden dolayı, peygamberine yapmış olduğu tebrik ve esenlik dileğidir.

Sözlükte, "boyun eğmek, emre itaat etmek, söz dinlemek, kabul etmek ve bir şeyi gönüllü olarak kabul etmek" gibi anlamlara gelen itaat (إطاعة) ve tâat (طاعة) kelimeleri, “ " $\varepsilon-g^{-b}$ (t-v-'a) kökünden türemiştir. İtaat kelimesi, kökünün if'âl babına katılmış (أطاع) mastarı, tâat ise "etâa" (أطاع) kelimesinden bir isimdir.136 İtaat kelimesi, çeşitli isim ve fiil türevleriyle birlikte Kur'ân'da yüz yirmi dokuz yerde geçmektedir. ${ }^{137}$

İtaat kelimesi, genel itibariyle bir emre uyulması için kullanılan bir ifadedir. Verilen bir emre uyma durumu da iradeye dayanmaktır. ${ }^{138}$ Beşerî yönden itaat, insan için kaçınamayacağı bir davranış şekli olmakla beraber itaatin objesini ihtiyarı hususunda insanoğlu hür bırakılmıştır. Bu manada bir varlığa itaat edip etmeme

130 el-İsrâ $17 / 23$.

131 Alaeddin Ali b. Muhammed b. İbrâhim el-Bağdadi el-Hâzin, Lübâbü't-te'vîl fî meâni't-tenzîl (Beyrut: Dâru'l-Fikr, 1979), 1/78, 522.

132 Râgıb el-İsfahânî, "asv", 339.

133 bk. Ebu'l-Hasan Mukâtil b. Süleyman b. Beșir, Tefsîr-u Mukâtil b. Süleyman, thk. Ahmed Ferid (Beyrut: Dâru'l-Kütübi'l-'İlmiyye, 2003), 2/308; Taberî, Câmi'u'l-beyân, 18/160; Beydâvî, Envâru't-tenz'il, 4/7; Ebü'l-Berekât Hafızüddin Abdullah b. Ahmed b. Mahmûd Nesefî, Medâriku't-tenzîl ve hakâiku't-te'vîl, thk. Yusuf 'Ali Büdeyvî (Beyrut: Dâru İbn Kesîr, 2005), 2/329; Ebû Hafs Ömer b. Ali Ed-Dimeșkî İbn Âdil, el-Lübâb fî ulûmi'l-kitâb, thk. 'Âdil Ahmed Abdülmevcud - Ali Muhammed Muavvaz (Beyrut: Dâru'l-Kütübi'l-'Ílmiyye, 1998), 13/27-28. 134 Meryem 19/14.

135 bk. İbn Âdil, el-Lübâb fî ulûmi'l-kitâb, 13/27.

136 İbn Manzûr, "tv'a", 30/2720-2721; Zebîdî, "tv'a", 21/462; Râgıb el-İsfahânî, "tv'a", 312.

137 bk. Fuâd Abdülbâkî, el-Mu'cemu'l-müfehres, "tv'a", 528-530.

138 Ebû Hilâl el-Hasen b. Abdillâh b. Sehl el-Askerî, el-Furûku'l-Lugaviyye, thk. Muhammed İbrahim Selim (Kahire: Dâru'l-İlim ve's-Sekâfe, ts.), 221. 
hususunda muhayyer bırakılan tek varlık da insandır. ${ }^{139}$ Zira konuyla ilgili bazı âyetlere bakıldığında insanoğlunun Allah'ın haricinde bazı kişi ve grupları itaatin objesi yaptığı durumların varlığı da anlaşılmaktadır. ${ }^{140}$ Bu manada ilgili âyette geçen itaat, kulun, Allah'a karşı itaatkâr olması, onun, Allah Teâlâ'nın emir ve buyruklarına uyma konusunda bilinçli/iradeli olarak emredileni yapıp nehyedilenden sakınması olarak ifade edilebilir.

Kur'ân'da, "Ey iman edenler! Allah'a itaat edin. Peygamber'e ve sizden olan ülü'l-emre (idarecilere) de itaat edin..." 141 ifadesiyle, itaat edilmesi gerekenler birkaç sınıf olarak zikredilmiş olsa da burada Allah'a itaat, kavramın temelini oluşturmaktadır ve mutlak anlamda itaat, sadece Allah'a özgüdür. Bu manada Fahreddîn er-Râzî, Allah'a ve Resulü'ne itaatin vacip olduğunu, yöneticilere itaatin ise vacip olmadığını ifade etmektedir. ${ }^{142}$ Benzer bir şekilde Kur'ân'da, mirasla ilgili bazı hükümler zikredildikten ${ }^{143}$ sonra, "Bunlar, Allah'ın (koyduğu) sınırlardır. Kim Allah'a ve Peygamberine itaat ederse Allah onu, altından irmaklar akan cennetlere koyacaktır; orada devamlı kalıcıdırlar, işte büyük kurtuluş budur."144 ifadeleriyle de Allah'ın koymuş olduğu kurallara itaatin karşılığının sonsuz cennet olduğu vurgulanmaktadır.

Yukarıda zikredilen ifadelerden başka Kur'ân'da Allah'a ve Resulüne itaat, iman etmenin sonucu ve mü'minliğin evsafları arasında sıralanmakta ${ }^{145}$ ve başkaca âyetlerde bu itaatin mükâfatlarından olarak, itaatkârların, sıddıklar, şehidler ve salihlerle birlikte olup ${ }^{146}$ ebedi kurtuluşa erecekleri147 ve yaptıkları güzel davranışlarının karşılığını da tam bir şekilde görecekleri ifade edilmektedir. ${ }^{148}$

İtaate en layık olan, dünyadaki her şeyi yoktan var eden ve istediği şekilde tasarrufta bulunan, kullukta ve tâatte yanına şerik tanımayan, yegâne hüküm ve hikmet sahibi Allah'tır. Sadece O'nun müsaadesi olduğu ölçüde başkasına itaat edilebilir ki bu da zaten O'na itaat demektir. Bu duruma örnek olarak Kur'ân'da “Kim Resule itaat ederse Allah'a itaat etmiş olur..."149 ifadesi verilebilir ki bu manaya göre Peygamber'e itaat, aynı zamanda Allah'a itaat olarak anlaşılmaktadır. Bu âyette ve başka bir âyette ${ }^{150}$ Allah'a itaatin tam manasıyla gerçeklik kazanması peygamberler aracılığıyla gerçekleşeceğinden, buralarda Allah'a itaatle peygambere itaat eş kılınmıştır. Hz. Peygamber'in “Kim bana itaat ederse şüphesiz Allah’a itaat etmiş

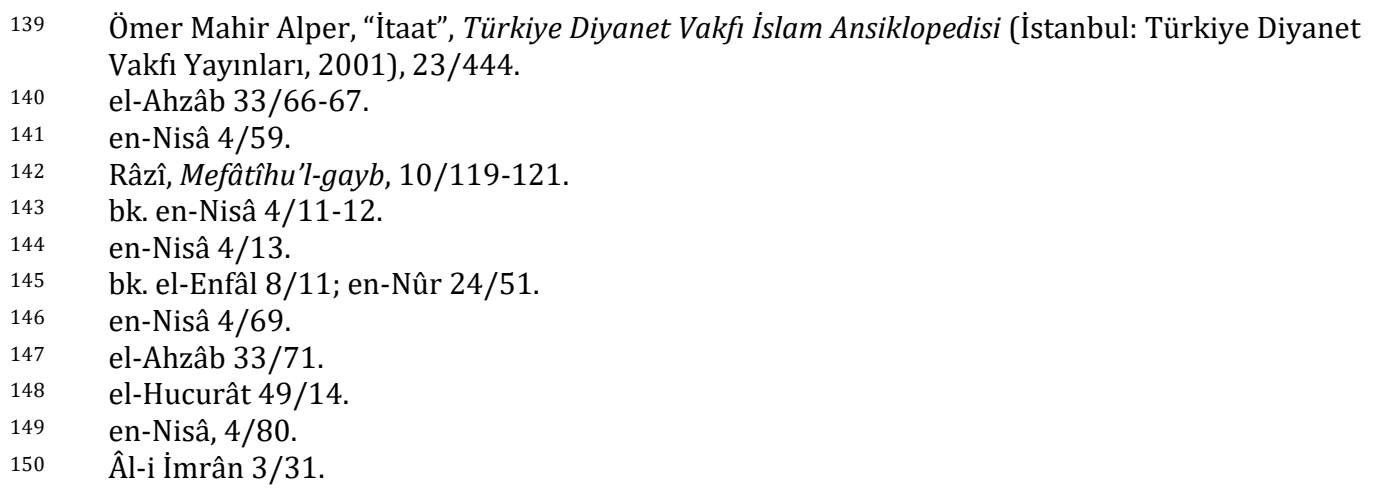


olur..."151 şeklindeki hadisi, O'na itaatin, Allah'a itaatin bir gereği olduğuna ve kendisine itaatin, Allah'a olan itaatin tamamlayıcı bir parçası olduğuna işaret etmektedir.

Kur'ân'da, kötü arzuların peşinden gidenlere,152 kâfirlere ve münafıklara,153 dini ve Hz. Peygamberi yalanlayanlara, ${ }^{154}$ evladına Allah'a ve elçisine eş koşması konusunda telkin veren ana babaya, ${ }^{155}$ din karşısında aşırı tavır takınmak suretiyle fesat çıkaranlara ${ }^{156}$ ve çokça yemin eden, başkalarının kusurunu arama gibi çirkin davranışlara sahip olanlara ${ }^{157}$ itaat edilmesi yasaklanmıştır.

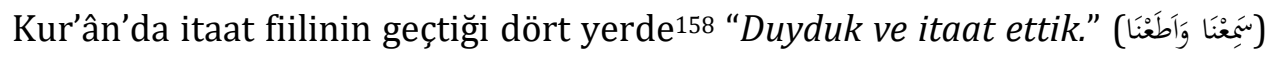

ifadesiyle ilişkilendirilmiş olması, itaatin gerçekleşmesinde anlayıp kavramış olmanın gerekliliğine işaret olarak değerlendirilmiştir. ${ }^{159}$ Buna göre Allah Teâlâ'nın selâmıyla esenliğine mazhar olabilmek için gerçekleştirilecek itaatin, bilinçsizce bir itaatten ziyade, Allah'ın ve elçisinin mesajının tam bir biçimde kavranması ve hakiki manada yaşanmasıyla gerçekleşeceği anlaşılmaktadır.

Fahreddin er-Râzî, Hz. Yahyâ ile ilgili âyette geçen ana babaya itaati, "Rabbin, sadece kendisine kulluk etmenizi, ana babanıza da iyi davranmanızı kesin bir şekilde emretti."160 âyetiyle ilişkilendirmektedir. Ayrıca "O, bir serkeş ve âsi değildi." âyetiyle de Hz. Yahyâ'nın tevazu ve yumuşaklıkla vasfedildiğini ifade ederek, aslında bu durumun mü'minlerin vasfı olduğunu ve benzer şekilde "Sana uyan mü'minlere (merhamet) kanadını indir."161 ve “...Sayet sen kaba, katı yürekli olsaydın, hiç şüphesiz, etrafından dağılıp giderlerdi..."162 âyetlerinde de aynı vasıflara işaret edildiğini belirtmektedir.163 Ayrıca Râzî, burada ifade edilen "selâm" ifadesini, diğer peygamberlerle karşılaştırarak Hz. Yahyâ'da diğer peygamberlere göre daha fazla meziyetin bulunduğuna değinmektedir. Buna göre, diğer bazı peygamberlere "Bütün âlemlerde Nûh'a selâm olsun!", 164 "Selâm olsun İbrâhîm'e..." 165 ve "Selâm olsun Mûsâ ve Hârûn'a!"166 şeklinde selâm verilirken, Hz. Yahyâ için "doğduğu günde"167 ifadesi kullanılmıştır ki bu da diğerlerine verilen selâmlarda geçmemektedir. ${ }^{168}$ Bu yönüyle

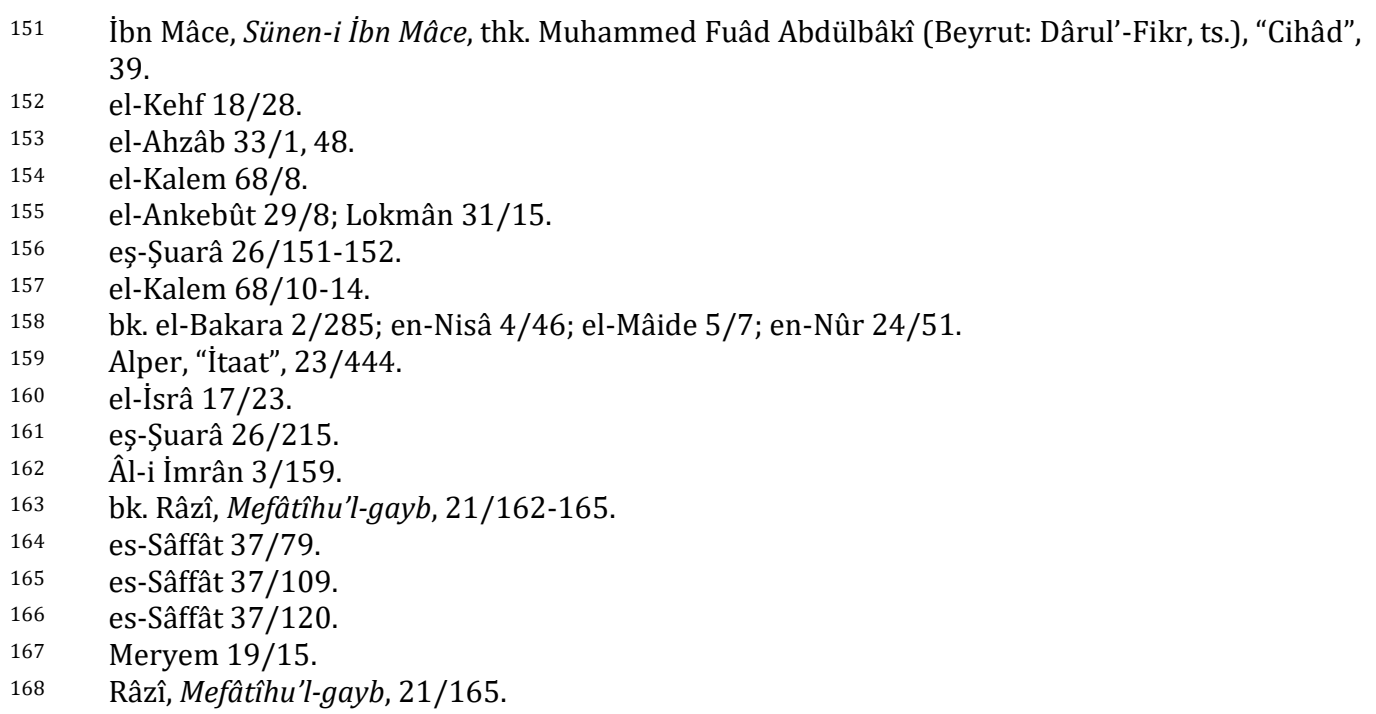


buradaki selâm ifadesi ön plana çıkmaktadır.

Ana baba hakkı, hadislerde de üzerinde titizlikle durulan konuların başında gelmektedir. Bu manada Hz. Peygamber'in "Ana babasından her ikisinin veya birinin yaşlılığına ulaşıp da onlar sebebiyle cennete giremeyen kimsenin burnu yere sürtülsün." 169 hadisi ana babanın ihtiyarlık çağında ihtiyaç duydukları bakımı üstlenmenin gereğine vurgu yapmakla birlikte, bu sorumluluğunu güzelce yerine getirenin mükâfatının cennet olduğunu müjdelemektedir. Hangi amellerin daha faziletli olduğu sorusuna verdiği cevapta Hz. Peygamber'in, ana babaya iyi davranmayı ikinci sırada söylemesi, ${ }^{170}$ onlara iyi ve güzel davranmanın faziletli bir davranış olduğuna; aynı şekilde başka bir hadisinde, ana babaya itaatsizliği büyük günahlar arasında zikretmesi, ${ }^{171}$ ana babaya kötü davranmanın, dinen geçerli bir mazereti olmadığına delil olarak değerlendirilebilir.

Kur'ân'da, İsrâiloğulları'ndan söz (mîsâk/ميثَاق) olarak alınmış davranışlar zikredilirken, ilk olarak sadece Allah Teâlâ'ya kulluk, sonra da ana babaya iyilik (ihsan) etme görevi sıralanmaktadır. ${ }^{172}$ İlgili âyette ana babaya itaat, evrensel bir değer olarak Allah hakkından hemen sonra ifade edilmekte, bu hakkı ve diğer bazı konuları ihlal edenler, sözlerinde durmayan kimseler olarak tanımlanmaktadır. Aynı şekilde, inananların ahlâkî anlamda takınması gereken görev ve sorumlulukları zikredilirken de ${ }^{173}$ benzer sıralamanın varlığı dikkat çekmektedir.

Allah'a iman ve kulluğun ardından ana babaya iyiliğin naslarda özellikle yan yana ifade edilmesi, belli başlı bazı sebeplere bağlanmaktadır. Bunlardan birincisi, bireyin gelişiminde en önemli katkı, Allah'ın vermiş olduğu nimetlerden sonra ana babanın evlâtları için yapmış oldukları fedakarlıklardır. Bu manada ana bana, evladın hem dünyaya geliş sebebi hem de bizzat onu terbiye edendir. İkincisi, çocukların dünyaya gelişlerinin gerçek sebebinin Allah Teâlâ, zahiri ve hukuki sebebininse ana baba olmasıdır. Üçüncüsü, Allah'ın tüm insanlığa nimetlerini karşılıksız vermesi gibi ebeveynin de çocuklarının ilgi ve ihtiyaçlarını karşılık beklemeksizin yapmasıdır. Dördüncüsü, günahkâr olmasına rağmen Allah Teâlâ'nın kullarına nimet vermesi gibi ana babanın da -evlâtları itaatkâr olmasa dahi- onları doyurmaya ve beslemeye devam etmeleridir. Sonuncusu ise Allah'ın kullarının yaptıkları güzel davranışlardan memnuniyeti sebebiyle karşılığını fazlasıyla vermesi gibi ana baba da evlâtlarının memnun oldukları değerleri devamlı olarak muhafaza etmeye çalışmalarıdır. ${ }^{174}$

Tefsirlerde, ana babaya güzel davranma ilkesinin Allah'a kullukla beraber zikredilmesine vurgu yapılarak, ${ }^{175}$ ilgili âyetlerde ${ }^{176}$ ana babaya saygının kendisiyle

Müslim, "Birr", 3.

bk. Buhârî "Cihad" 1.

bk. Buhârî “Edeb" 6; Müslim, "İman”, 38; Tirmizî, "Birr”, 4.

el-Bakara 2/83.

bk. el-En'âm 6/151-153.

bk. Râzî, Mefâtîhu'l-gayb, 3/150; Hâzin, Lübâbü't-te'vîl, 2/199.

Râzî, Mefâtîhu'l-gayb, 3/150-151; Hâzin, Lübâbü't-te'vîl, 1/522.

bk. el-Bakara 2/83; en-Nisâ 4/36; el-En'âm 6/151; el-İsrâ 17/23; el-Ahkâf 46/15. 
ifade edildiği "ihsan" (إِحسَانان) lafzının nekre formuyla gelmesinin manaya çokluk kattığı ifade edilmiştir. Buna göre Allah Teâlâ'nın yapılmasını emrettiği ihsan kavramı hayatta ne kadar uygulanma imkânı bulursa o kadar uygulanması gerektiği anlaşılmaktadır. "İhsan"ın, ana babanın akabinde zikredilmesinin manaya mübalağa kattığı da ifade edilmiştir. Bu düşüncenin sonucu olarak da ebeveyne iyi davranma hususunda ihsan ne kadar abartılırsa, bu durumun âyette verilmek istenen mesaja o kadar uygun olacağı da ifade edilmiştir. ${ }^{177}$ Ayrıca "ihsan" ve ebeveyni mutlu ettirip onlara hizmet etme gibi durumları da kapsadı̆̆ belirtilmiştir. Bu manada Kur'ân'da ana baba hakkının Allah hakkından sonra anılmasının, sıralamada O'nun hakkının peşinden geldiğinin ve insanî diğer haklar karşısında önceliği bulunduğunun da bir delili olarak ifade edilmiştir. ${ }^{178}$

Kur'ân'da, evlâtlar tarafından sorumlulukların yerine getirilmesi hususunda ana baba arasında herhangi bir ayrım yapılmamıştır. Buna göre, ebeveynin her ikisine de güzel muamele edilmesi gerektiği anlaşılmaktadır. Fakat yine de annenin özellikle annelik başlangıcı ve sonrası olmak üzere evladına verdiği fazlaca zahmete ve emeğe ayrıca vurgu yapılmıștır. Konuyla ilgili Lokmân Sûresi'nde geçen "Biz insana, ana babasına iyi davranmasını tavsiye etmişizdir. Çünkü anası onu karnında nice sıkıntılara katlanarak taşımıştır. Sütten ayrılması da iki yıl içinde olur. (İşte bunun için) önce bana, sonra da ana babana şükret diye tavsiyede bulunmuşuzdur..."179 ifadeleriyle Allah Teâlâ'nın, ebeveynin çocukları için önceden katlandıkları sıkıntıları sebebiyle kendilerine itaati emrettiği anlaşılmaktadır. Buna göre itaatin gerekçelerinden birinin, ana babanın evladını bin bir zorluk ve sıkıntıyla dünyaya getirip büyütmesi olduğu anlaşılmaktadır.

"Rabbin, sadece kendisine kulluk etmenizi, ana babanıza da iyi davranmanızı kesin bir șekilde emretti. Onlardan biri veya her ikisi senin yanında yașlanırsa, kendilerine 'öf!' bile deme; onları azarlama, ikisine de güzel söz söyle. Onları esirgeyerek alçak gönüllülükle üzerlerine kanat ger ve: 'Rabbim! Küçüklüğümde onlar beni nasıl yetiştirmişlerse, şimdi de sen onlara (öyle) rahmet et!' diyerek dua et!"180 âyetlerine bakıldığında yukarıda belirtilenlerle benzer sonuca ulaşmak mümkün gözükmektedir. ${ }^{181}$

Zikredilen tüm değerlendirmelerden anlaşılmaktadır ki Kur'ânî açıdan ahlâkî bir davranış sergileme gayreti ana babaya hak ettikleri değeri vermeyi gerekli kılmaktadır. Sadece ebeveynde bulunan evlât sevgisi ve şefkati dikkate alınsa dahi onların çocuklarını büyütme, eğitme ve yetiştirme konularındaki çaba ve gayretleri nedeniyle de bu iyiliği hak ettikleri düşünülebilir. ${ }^{182}$ Bu manada Kur'ân'da annenin

\footnotetext{
177 Râzî, Mefâtîhu'l-gayb, 20/149.

178 Mevdûdî, Tefhîmu'l-Kur'ân, 3/103.

179 Lokmân 31/14.

180 el-İsrâ $17 / 23-24$.

181 Ayrıca bk. Râzî, Mefâtîhu'l-gayb, 3/151.

182 Mustafa Kara, Bireysel ve Toplumsal Açıdan Kur'ân Kıssaları (Samsun: Üniversite Yayınları, 2018), 265.
} 
hem hamileliği döneminde hem de yavrusunu dünyaya getirirken katlandığı zorluklardan bahsedilmesi ${ }^{183}$ aslında durumu özetler mahiyettedir. Bu nedenledir ki Hz. Peygamber, evladın ebeveynin hakkını tam manasıyla ödeyebilmesinin mümkün olmadığına vurgu yapmıştır. ${ }^{184}$

Kur'ân'da ana babaya saygı ve hürmet konusu çok defa geçmekle birlikte Allah'a kulluğun hemen peşinden ifade edilmesi, bu davranışın farz olduğuna işaret olarak yorumlanabilir. ${ }^{185}$ İlgili bazı âyetlere ${ }^{186}$ ve kaynaklara ${ }^{187}$ bakıldığında ebeveynin mü'min vb. olup olmadığına bakılmaksızın onlara iyi davranmanın gerekliliği anlaşılmaktadır. Fakat bazı âyetlerde ${ }^{188}$ bu duruma istisna olarak getirilen durum, ebeveynin çocuklarını Allah'a eş koşmak gibi bir taleple gelmeleri halidir. Bu âyetlerde Kur'ân'da son derece etkili bir biçimde vurgulanan ana babaya itaatin sınırları da çizilmiş olmaktadır. Ayrıca Hz. Peygamber'in, "Allah Teâlâ'ya isyan sayılabilecek bir hususta bir kula itaat edilmez!"189 meâlindeki hadisi de ilgili âyetleri açıklar mahiyettedir. Buna göre İslâm ahlâkında kendilerine itaatin çok önemli olduğu ebeveynin, dinen yasak olan hususlardaki taleplerinin dikkate alınmaması; yasak olmayan durumlarda ise isteklerinin yerine getirilmesi gerektiği anlaşılmaktadır. Böylelikle ana babaya güzel davranma emrinin, ebeveyn tarafından istismar edilmesinin de önüne geçilmiş olur.

Kur'ân'da ebeveynle evlâtları arasındaki ilişkinin ve duygusal bağın önemi, bazı peygamberlerin hayatlarından kesitler sunan kıssalarda öne çıkarılmıştır. Buna göre Hz. Nûh'un, inkârda ısrarcı olması hasebiyle, oğluna tufanda gemiye gelmesi için gösterdiği çaba, ${ }^{190} \mathrm{~Hz}$. Yûsuf'un başından geçen tüm olumsuz durumlar, babası Hz. Ya'kûb'a iltifatı191 ve beraber çektikleri ayrılık hasreti, ${ }^{192}$ Firavun tarafından öldürülme kaygısını iliklerine kadar yaşayan annesinin, Hz. Mûsâ'yı kurtarmak için verdiği çabası ${ }^{193}$ ve Hz. İsmail'in babasına itaati ${ }^{194}$ ile ana babanın evlâtlarıyla olan karşılıklı sevgi ve merhametleri gündeme getirilmiştir.

Kur'ân'da, Hz. İbrâhim'le babası arasında geçen diyalogu anlatan âyetler,195 bir çocuğun ana babasına olması gereken davranış biçimini göstermesi bakımından dikkat çekmektedir. Buna göre Hz. İbrâhim'in, babası Âzer'e söylediği sözlerin başında “Babacı̆ğım!” (يَا آََبَ) şeklindeki hitabı; babasının onun davetini kabul etmeyip, son derece tehditkâr sözler kullanmasına karşın yine de ona olan hürmetini muhafaza

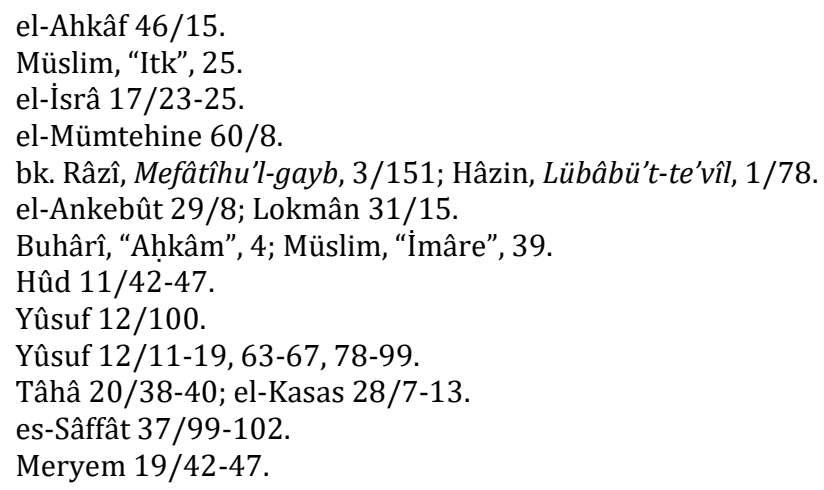


ederek, "Selâm olsun sana, rabbimden senin için af dileyeceğim."196 demesi, itaatin keyfiyetini gösteren güzel örneklerden biridir.

Ebeveyn, evladını Allah'a isyana davet etmedikçe, evlâtların onların meşrû olan her emrine itaat etmeleri gerekir. Hz. Peygamber'in, müşrik olan bir anneye sılai rahimde bulunarak ona iltifatlarda bulunmayı emretmesini de bu bağlamda değerlendirmek mümkündür. ${ }^{197} \mathrm{Bu}$ manada, müşrik de olsalar, ana babaya güzel davranmak, ikramda kusur etmemek, dinimizin buyruğudur. Ayrıca Kur'ân'da, ana babaya iyi davranmak, iyilik yapmak, ${ }^{198}$ onlara karşı iyi niyetli olmak, ${ }^{199}$ kötü sözden sakınmak, güzel söz söylemek ${ }^{200}$ ve hesap gününde onlar için mağfiret talebinde bulunmak ${ }^{201}$ gibi durumlar bizzat emredilmektedir. Aslında bu durumların hepsini ana babaya ihsan etmek, güzel davranmak kategorisi içerisinde değerlendirmek de mümkündür.

Çocukların, ebeveynlerinin kendilerinden beklentisi olan hayırlı evlât olma beklentisini gerçekleştirebilecekleri en iyi zaman dilimi, an babanın sevgiye, ilgiye, merhamet ve şefkate en çok ihtiyaç duydukları yaşlılıkları dönemidir. Bu manada belki de yukarıda zikredilen bazı âyetlerde çocukların küçükken ailelerinin katlandıkları sıkıntılara vurgu yapılması, buradan hareketle ebeveyne itaatin emredilmesi bu sebeple olabilir. Kendi gençliklerinde gözlerinden sakındıkları evlâtları uğruna zorluklara katlanan ana babanın, çocukları tarafından iyi muamele görmeyi hak ettikleri aşikardır. Bu nedenle olmalıdır ki Hz. Yahyâ'nın ana babasına

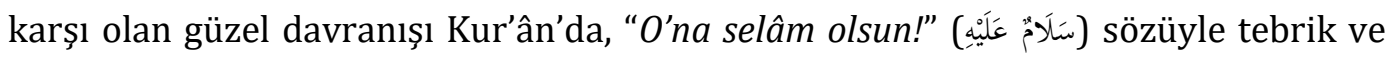
esenlik dilenerek anılmıştır.

\section{4. İyi İşler Yapmak}

Kur'ân'da cennete girmeyi hak eden mü'minler için melekler tarafından kendilerine müjdeli haberlerin verileceğini haber veren âyetlerden biri "(Onlar,) meleklerin, 'Size selâm olsun. Yapmış olduğunuz (iyi) işlere karşılık cennete girin!'

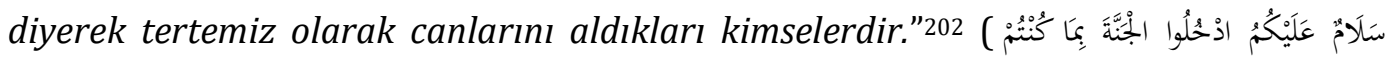

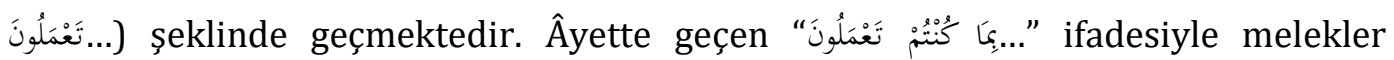
tarafından tebrik edilen mü'minlerin cennete girme gerekçelerine dikkat çekilmektedir. Buna göre onların dünyada iken yaptıkları sebebiyle hem esenlik dilenmeye hem de cennet nimetine mazhar oldukları anlaşılmaktadır.

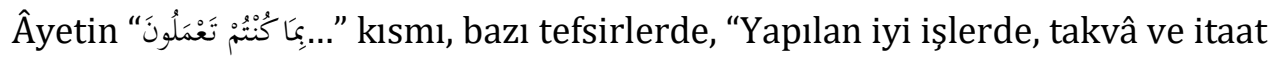

\footnotetext{
196 Meryem 19/47.

197 Müslim, "Zekât" 50.

198 el-Bakara 2/83; en-Nisâ 4/36; el-En'âm 6/151; el-İsrâ 17/23; el-Ankebût 29/8; el-Ahkâf 46/15.

199 el-İsrâ $17 / 24-25$.

200 el-İsrâ $17 / 23$.

201 İbrâhîm 14/41.

202 en-Nahl 16/32. Diğer âyetler için bk. el-Enbiyâ 21/103; el-Ahzâb 33/44.
} 
üzere sebat etmek"203 ve "dünyada iken takvâlı yaşamak"204 ifadeleriyle açıklanmakla birlikte, âyete genel olarak "Dünyada yaptığınız amellerin karşılı̆̆ı olarak cennete girin!" manası verilmektedir. ${ }^{205}$ Buna göre ilgili âyette ifade edilen mananın, dünyada yapılan güzel davranışlar sebebiyle cennetin hak edildiği ${ }^{206}$ şekliyle anlaşılmasının daha uygun düşeceği söylenebilir. Âyette mü'minlere hitaben meleklerin "Selâm size; yaptıklarınıza karşılık olarak girin cennete!" manasındaki sözlerinden de anlaşıldığı gibi mü'minlerin cennete girmelerinde iyi ve güzel amellerinin rolü olduğu anlaşılmaktadır.

İyiliğin sınırlarının neler olduğu veya neleri kapsadığı Kur'ân ve hadislerde net olarak belirlenmemekle birlikte, kapsama alanının çok geniş olduğu söylenmelidir. Bu manada iyiliği emredip kötülükten sakındırmak, iyiliğe davet etmek ve bu konuda yarışmak Kur'ân'da zikredilen mü'min vasıflarının başında gelmektedir. ${ }^{207}$ Ayrıca "Kim iyi iş yaparsa faydası kendinedir..."208 ifadesi de iyiliğin karşıllğının olumlu olarak tekrar görüleceğini haber vermektedir. Buna göre mü'minin, sadece kendisi iyi kimse olan değil, aynı zamanda diğer insanların da iyiliğini arzulayan ve onlara iyiliği ve güzelliği tavsiye ederek bu konuda yol gösteren insan olduğu anlaşılmaktadır.

Kur'ân'da geçen ve Bakara Sûresinin gerdanlığı olarak ifade edilen²09 âyette ${ }^{210}$ iyiliğin, yüzleri doğu ve batıya çevirmenin değil; Allah'a, ahiret gününe, meleklere, kitaplara, peygamberlere inanmanın yanında bir de yakınlara, yetimlere, yoksullara, yolda kalmışlara, dilenenlere ve kölelere sevilen mallardan harcanılmasının hatırlatılması iyilik kavramının çok kapsamlı olduğu anlaşılmaktadır. Bu nedenle olmalıdır ki iyilik kavramı "saygı ifade eden bütün davranışları, itaatleri ve insanı Allah'a yaklaştıran hayırlı işleri içine alan bir kelime" 211 olarak tanımlanmıştır.

Hadislerde, iyilik yapmak, iyi insan olmak ve iyilikte yardımlaşmak kadar, bir kimseyi kötülükten sakındırmak da Müslümanın vazifeleri arasında zikredilmektedir.212 Bu manada kötülükten sakındırmak, sonucu itibariyle başkasına yapılmış bir iyiliktir. Mü'min, büyük olsun küçük olsun gördüğü bir kötülüğü, düzeltmeye, bunu yapamıyorsa ona mâni olmaya çalışmalıdır. Buna da gücü yetmezse

\footnotetext{
203 Muhammed Ebüssuûd, İş̧âdu'l-'akli's-selîm ilâ mezâye'l-Kur'âni'l-Kerîm, thk. Abdulkâdir Ahmed 'Atâ (Beyrut: Dâru İhyâi't-Türâsi'l'Arabî, ts.), 5/111.

204 Ebü's-Senâ Șihâbüddîn Mahmûd b. Abdillâh b. Mahmûd el-Hüseynî el-Âlûsî, Rûhu'l-me'ânî fi tefsîri'l-Kur'âni'l-Azîm ve's-seb 'i'l-mesânî (Beyrut: Dâr-u İhyâi't-Türâsi'l-'Arabî, ts.), 14/134.

205 Bk. Kurtubî, el-Câmi' li ahkâmi'l-Kur'ân, 10/102; Nesefî, Medâriku't-tenzîl, 2/211; Hâzin, Lübâbü't-te'vîl, 4/89.

206 Bk. Ebû Muhammed Abdülhak b. Gâlib İbn 'Atiyye el-Endelüsî, el-Muharraru'l-vecîz fí tefsiri'lkitâbi'l-azîz, thk. Abdüsselam Abduşşâfî Muhammed (Lübnan: Dâru Kütübi'l-'Ílmiyye, 1993), 3/389.

207 bk. Âl-i İmrân 3/104, 110; el-Mâide 5/2; et-Tevbe 9/71.

208 el-Câsiye 45/15.

209 Mahmûd Şeltût, "Bakara Sûresi'nin Gerdanlığı Birr (İyilik) Âyetinin Tefsiri”, Tasavvuf İlmî ve Akademik Araştırma Dergisi, çev. İdris Şengül, $3 / 7$ (2001), 321. el-Bakara 2/177.

Râzî, Mefâtîhu'l-gayb, 5/31-33.

Müslim, "Fiten", 26; Tirmizî, "Fiten", 71.
} 
nasihat etmek suretiyle kişilere yaptıklarının yanlış olduğunu hatırlatarak, onları yaptıklarından vazgeçirmeye çalışmalıdır.

Hz. Peygamber'in “Ümmetimin iyi-kötü bütün amelleri bana gösterildi. İyi işlerinin içinde, gelip geçenlere eziyet veren şeylerin yollardan kaldırılmasını da buldum..." 213 ve "Kardeşini güler yüzle karşılamaktan ibaret dahi olsa, hiçbir iyiliği küçük görme!" 214 şeklindeki hadisleri de üzere iyiliğin sınırlarının çok geniş olduğunu haber vermektedir. Bu minvalde değerlendirilebilecek iyilik çeşitliliği, insanın kendi şahsına ve ailesine karşı vazifelerini bihakkın yerine getirmesi, komşusuyla olan ilişkilerine dikkat ederek her konuda ona yardım etmesi, yetimi, yoksulu, yaşlı ve kimsesizleri görüp gözetmesi, çevresindeki insanlara iyilikleri tavsiye etmesi, misafirini hoşnut etmesi, yolda veya çevrede insanları rahatsız eden bir eziyeti kaldırması, kısacası dinin yapılmasını istediği davranışları akıl ve vicdanın hoş gördüğü bir şeyi yapması iyilik olarak ifade edilebilir. En genel ifadeyle de bunların tümünü yaşama gayreti içerisinde olmak ve bunları yeryüzüne hâkim kılmaya çalışmak iyiliktir. ${ }^{215}$

Geniş iyilik kategorisi içerisinde herkesin yapabileceği bir iyilik mutlaka vardır. Bunun yanında mü'min, iyilik yapmakla yetinmeyip başkalarının da bu iyilikleri yapmasına yardım etmelidir. Bu konularda başkalarını da daima teşvik etmelidir. Bu manada Allah Teâlâ'nın "emir bi'l-ma'rûf nehiy 'ani'l-münker" hususunda inananların yardımlaşması gerektiği emri de hatırlanmalıdır. ${ }^{216}$

Saymakla bitirilemeyecek kadar fazla olan iyi ve güzel hasletlerin, âdeta bir yarış edasında yapılması gayreti her Müslümanın görevidir. Bu dünyada iyilik hasletini Allah'ın istediği şekilde hayata geçirenler, bu dünyada ve ahirette karşılığında iyilik bulacaklardır. Bu hususta yapılacak olan duanın keyfiyeti Kur'ân-ı Kerîm'de “...Ey Rabbimiz! Bize dünyada da iyilik ver, ahirette de iyilik ver...”217 ifadesiyle yer bulmaktadır. Sadece Allah için iyi olan ve iyilik yapan, başkalarına maddî ve manevî yardımda bulunan kimsenin ecri Allah Teâlâ'nın "selâm"ına mazhar olarak, esenlik dilenmek suretiyle melekler tarafından, güzel bir müjdeyle cennette verilecektir.

\section{Sonuç}

İslâm inancına göre bu dünyada yaşananlar dünyayla sınırlı kalmayacak, yaşantının karşılığı ahirette görülecektir. Bu durum Kur'ân'da, insanların dünyadaki yaşantılarının keyfiyetine göre ahirette çeşitli mükâfat veya ceza ile karşılaşacaklarını haber veren âyetlerden anlaşılmaktadır. Buna göre Allah Teâlâ'nın istediği şekilde yaşamanın gayreti içerisinde olanlar ahirette mükâfat, aksi durumda olanlar ise ceza

\footnotetext{
213 Müslim, "Mesâcid", 57; İbni Mâce, "Edeb", 7.

214 Müslim, "Birr", 144.

215 Osman Çetin, "İyilik", Şâmil İslâm Ansiklopedisi, ed. Duran Kömürcü, (İstanbul: Şâmil Yayınevi, 2000), 4/205.

216 el-Bakara 2/148; el-Mâide 5/2; el-Mü'minûn 23/57-61; Fâtır 35/33.

217 el-Bakara $2 / 201$.
} 
ile karşılaşacaklardır.

Kur'ân'a göre, dünyada Allah Teâlâ'nın istediği şekilde yaşayıp cenneti hak edenlere sayısız nimet verilmekle birlikte, onların karşılaşacakları büyük mükâfatlardan birinin de ahirette selâm sözüyle karşılanma olduğu haber verilmektedir. Bazı durumlarda cennetlikleri karşılayanlar melekler olsa da aslında cennet olması hasebiyle ve Allah Teâlâ'nın da selâmladığının örnekleri olması hasebiyle tüm "Selâm olsun!" ifadesini içeren karşılanmayı aynı derecede mükâfat bağlamında değerlendirmek mümkündür.

Hidayet kaynağı olması hasebiyle Kur'ân'da anlatılan kıssa ve olaylarda genel olarak isim zikredilmediği gibi daha çok, yapılan davranışlara işaret çekilerek o davranışlar övülmekte veya yerilmektedir. Kur'ân'da isimlerden değil, daha çok tavır ve davranışlardan söz edilmektedir. Bu üslûbuyla Kur'ân'ın amacı muhataplarına tanıtmaya çalıştığı Firavun veya Ebû Leheb (kişiler) değil, Firavunluk veya Ebû Leheplik yani kişiliktir. Bu manada, peygamberler dışında iyi insanların da isimleri anılmaz; fakat yaptıkları övgüye layık davranışlara vurgu yapılır. Kur'ân'da kullanılan üslûb dikkate alındığında da şahıslardan çok davranışların ön planda olduğu anlaşılmaktadır.

Bu manada Kur'ân'da "Selâm olsun!” ifadesiyle esenlik dilenen durumlara bakıldığında bunların ya ismen belirtilen bir peygamberin veya gerçekleştireni belli olmadan dikkat çekilen bir davranışın bağlamında (gıyaben) zikredildiği görülmektedir. Bu yönüyle ifadelerin kullanılmasına neden olan davranışlara dikkatler çekilmekte ve bu selâma nâil olabilme adına bunları tespit etmenin gerekliliği hatıra getirilmektedir.

Karşılaşılan musibetlerin ve sıkıntıların, yapılması gereken ibadetlerin ve sakınılması gereken haramların getireceği tüm sıkıntılara karşı tahammül/direnç göstermek, bu hususlarda şeytana ve nefse değil, Allah'a ve Resulüne tabi olmak şeklinde tanımlanan sabretmek; Allah'ın emirlerine uymak, yasaklarından da kaçınmak suretiyle korunmak ve bu hususta titizlik göstermek olarak tanımlanan takvâ sahibi olmak ve ayrıca daima iyi işler yapmak, Allah'a âsi olmamak ve ana babaya iyi davranmak gibi hasletlerin Kur'ân'da, sonucunda selâm ifadesiyle ahirette karşılanmaya layık davranışlardan olduğu anlaşılmaktadır.

Selâm sözüyle Allah Teâlâ tarafından ahirette karşılanma nimetine ulaşabilmenin, Kur'ân'ın ilgili âyetlerinde yapılması gereken bazı eylemlerin gerçekleștirilmesine bağlı olarak zikredilmesi, -söylem-eylem bağlamındainananların söylemlerini eyleme dönüştürmeleri sonucunda gerçekleşeceği hususunu da tekrar hatırlatmaktadır. 


\section{Kaynakça}

Abdülbâkî, Muhammed Fuâd. el-Mu'cem'ul-müfehres. Kahire: Dâru'l-Hadîs, 2001.

Akyüz, Vecdi. Kur'an'da Siyasi Kavramlar. İstanbul: Kitabevi Yayınları, 1998.

Alper, Ömer Mahir. "İtaat" Türkiye Diyanet Vakfi İslam Ansiklopedisi. 23/444-445. İstanbul: Türkiye Diyanet Vakfı Yayınları, 2001.

Âlûsî, Ebü's-Senâ Şihâbüddîn Mahmûd b. Abdillâh b. Mahmûd el-Hüseynî. Rûhu'l-me'ânî fi tefsîri'l-Kur'âni'l-azîm ve's-seb 'i'l-mesânî. 30 Cilt. Beyrut: Dâr-u İhyâi't-Türâsi'l-'Arabî, ts.

Askerî, Ebû Hilâl el-Hasen b. Abdillâh b. Sehl. el-Furûku'l-Lugaviyye. thk. Muhammed İbrahim Selim. Kahire: Dâru'l-İlim ve's-Sekâfe, ts.

Ateș, Süleyman. Kur'ân-ı Kerîm Tefsiri. 6 Cilt. b.y.: Bilmar Yayıncllık, ts.

Ayverdi, İlhan. Misalli Türkçe Sözlük. 3 Cilt. İstanbul: Kubbealtı, 2011.

Beydâvî, Abdullah b. Ömer b. Muhammed. Envâru't-tenzîl ve esrâru't-te'vîl. thk. Muhammed Abdurrahman el-Maraşlı. 5 Cilt. Beyrut: Daru İhyai't-Turasi'l-Arabî, 1997.

Bolelli, Nusreddin. Belâgat. İstanbul: Marmara Üniversitesi İlahiyat Vakfı Yayınları, 2006.

Buhârî, Ebû Abdillah Muhammed b. İsmail. Sahîhu'l-Buhârî. thk. Mustafa Dîb el-Buğa. 6 Cilt. Beyrut: Dâru İbn Kesîr, 1987.

Çağbayır, Yaşar. Ötüken Türkçe Sözlük. İstanbul: Ötüken Yayınları, 2007.

Çetin, Osman. "İyilik" ed. Duran Kömürcü. Şâmil İslâm Ansiklopedisi. 4/204-206. İstanbul: Şâmil Yayınevi, 2000.

Durmuş, Zülfikar. Kur'an'a Göre Kur'an. İstanbul: Rağbet Yayınları, 2012.

Ebû Hafs Ömer b. Ali Ed-Dimeşkî, İbn Âdil. el-Lübâb fî ulûmi'l-kitâb. thk. 'Âdil Ahmed Abdülmevcud - Ali Muhammed Muavvaz. 20 Cilt. Beyrut: Dâru'l-Kütübi'l-'Illmiyye, 1998.

Ebû Muhammed Abdülhak b. Gâlib, İbn 'Atiyye el-Endelüsî. el-Muharraru'l-vecîz fî tefsiri'lkitâbi'l-azîz. thk. Abdüsselam Abduşşâfî Muhammed. 5 cilt. Lübnan: Dâru Kütübi'l'İlmiyye, 1993.

Ebüssuûd, Muhammed. İrşâdu'l-'akli's-selîm ilâ mezâye'I-Kur'âni'l-Kerîm. 9 Cilt. Beyrut: Dâru İhyâi't-Türâsi'l'Arabî, ts.

Ferâhîdî, Ebû Abdirrahman Halil b. Ahmed. Kitâbu'l-'ayn. thk. Mehdî Mahzûmî ve İbrahim Samraî. Cilt 8. b.y.: y.y., ts.

Eyyûb b. Mûsâ el-Hüseynî Ebü'l-Bekâ, el-Kefevî. el-Külliyyât. thk. 'Adnan Dervîş - Muhammed el-Mısrî. Beyrut: Müessesetü'r-Risale, 1998.

Hamidullah, Muhammed. İslam'a Giriş. Ankara: Nur Yayınları, ts.

Hâzin, Alaaddin Ali b. Muhammed b. İbrâhim el-Bağd. Lübâbü't-te'vîl fî meâni't-tenzîl. 7 Cilt. Beyrut: Dâru'l-Fikr, 1979.

İbn Fâris, Ebu'l-Hüseyn Ahmed. Mu'cemu mekâyîsi'l-luga. thk. Abdüsselam Muhammed Harun. 6 Cilt. b.y.: Dâru'l-Fikr, 1979.

İbn Manzûr, Ebü'l-Fazl Muhammed b. Mükerrem b. Ali el-Ensârî. Lisânü'l-'Arab. 55 Cilt. Kahire: Dâru'l-Maârif, ts.

İz, Mâhir. Din ve Cemiyet. İstanbul: İrfan Yayınevi, 1973.

İzutsu, Toshihiko. Kur'an'da Dînî ve Ahlâkî Kavramlar. çev. Selahattin Ayaz. İstanbul: Pınar Yayınları, 2013.

İzutsu, Toshihiko. Kur'an'da Tanrı ve İnsan. çev. M. Kürşad Atalar. İstanbul: Pınar Yayınları, 2012.

Kara, Mustafa. Bireysel ve Toplumsal Açıdan Kur'ân Kıssaları. Samsun: Üniversite Yayınları, 2018.

Karagöz, İsmail. “Kur'an'da Takvâ Kavramı ve Muttakî İnsanın Özellikleri” Diyanet İlmi Dergi, 4 (1995), 49-61. 
177 | Kur'ân’da “Selâm Olsun!” Ifadesiyle Esenliğe Mazhar Olacağı Belirtilen Davranışlar

Karagöz, İsmail. "Kur'an ve Hadislerin Işığında Sabır ve İnsan” Diyanet İlmi Dergi 38/1 (2002), $5-22$.

Karaman, Hayrettin, vd. Kur'an Yolu: Türkçe Meâl ve Tefsir. 5 Cilt. Ankara: Diyanet İşleri Başkanlığı Yayınları, 2007.

Kasapoğlu, Abdurrahman. "İslâm'da Selâm ve Selâmlaşma Olgusu" Hikmet Yurdu Düşünce Yorum Sosyal Bilimler Araştırma Dergisi 3/6 (Temmuz-Aralık 2010), 49-87.

Kılavuz, Ahmet Saim. "Sabûr" ed. İbrahim Kâfi Dönmez. İslam'da İnançi İbadet ve Günlük Yaşayış Ansiklopedisi. 4/1709. İstanbul: Marmara Üniversitesi İlahiyat Vakfı Yayınları, 2006.

Koç, Ahmet. “Dinî İletişim Bağlamında Kur'an'da “Kavl” (Söz) Çeşitleri” Diyanet İlmi Dergi 43/4 (2008), 29-50.

Kurtubî, Ebû Abdullah Muhammed b. Ahmed b. Ebî Bekr. el-Câmi' li ahkâmi'l-Kur'ân. thk. Ahmed el-Berdûnî ve İbrahim Etfıyyiș. 20 Cilt. Kahire: Dâru'l-Kütübi'l-Mısrî, 1964.

Mâce, İbn. Sünen-i İbn Mâce. thk. Muhammed Fuâd Abdülbâkî. 2 Cilt. Beyrut: Dâru'l-Fikr, ts.

Mevdûdî, Ebu'l-A'lâ. Tefhîmu'l-Kur'ân. çev. Muhammed Han Kayani vd. 7 Cilt. İstanbul: İnsan Yayınları, 2006.

Mîr, Muntasır. Kur'ânî Terimler ve Kavramlar Sözlügü. çev. Murat Çiftkaya. İstanbul: İnkılâb Yayınları, 1996.

Mukâtil b. Süleyman, Ebu'l-Hasan b. Beşir. Tefsîru Mukâtil b. Süleyman. thk. Ahmed Ferid. Beyrut: Daru'l-Kütübi'l-İlmiyye, 2003.

Müslim, Ebu'l-Hüseyin el-Kușeyrî. Sahîh-u Müslim. thk. Muhammed Fuâd Abdülbâki. 5 cilt. Beyrut: Dâru İhyâi't-Türâsi'l-'Arabiyye, ts.

Nesefî, Ebu'l-Berakât. Medâriku't-tenzîl ve hakâiku't-te'vîl. thk. Yusuf 'Ali Büdeyvî. Beyrut: Dâru İbn Kesîr, 2005.

Parlatır, İsmail vd. Türkçe Sözlük. 2 Cilt. Ankara: Türk Tarih Kurumu Basım Evi, 1998.

Püsküllüoğlu, Ali. Türkçe Sözlük. İstanbul: Can Yayınları, 2008.

Râgıb el-İsfahânî, Ebu'l-Kâsım Hüseyin b. Muhammed. el-müfredât fí garîbi'l-Kur'ân. Beyrut: Dâru'l-Marife, 2005.

Râzî, Ebû 'Abdullah Fahreddîn. Mefâtîhu'l-gayb. 32 Cilt. Beyrut: Dâru'l-Kütübi'l-'İlmiyye, 2000.

Sami, Şemseddin. Kamus-ı Türkî. Ankara: Türk Dil Kurumu Yayınları, 2015.

Soysaldı, Mehmet. Kur'an-ı Kerim'e Göre Allah Kimleri Sever Kimleri Sevmez? İstanbul: Rağbet Yayınları, 2015.

Suyûtî, Ebü'l-Fazl Celaleddin Abdurrahman b. Ebî Bekr. el-İtkân fí ulûmi'l-Kur'ân. thk. Ahmed b. Ali. 2 Cilt. Kahire: Dâru'l-Hadîs, 2004.

Şeltût, Mahmûd. "Bakara Sûresi'nin Gerdanlığı Birr (İyilik) Âyetinin Tefsiri" çev. İdris Şengül. Tasavvuf İlmî ve Akademik Araștırma Dergisi 3/7 (2011), 321-335.

Taberî, Ebû Ca'fer Muhammed b. Cerîr b. Yezîd el-Âmülî. Câmi'u'l-beyân an te'vîli âyi'l-Kur'ân. thk. Ahmed Muhammed Şakir. 24 cilt. b.y.: Müessesetü'r-Risale, 2000.

Tirmizî, Muhammed b. İsa. Sünenü't-Tirmizî. thk. Ahmed Muhammed Şakir. 5 Cilt. Beyrut: Dâru İhyâi't-Türâsi'l-'Arabiyye, ts.

Toven, Mehmet Bahaettin. Yeni Türkçe Lügat. Ankara: Türk Dil Kurumu Yayınları, 2015.

Ünal, Ali. Kur'an'da Temel Kavramlar. İstanbul: Beyan Yayınları, 1990.

Yazır, Elmalılı Muhammed Hamdi. Hak Dini Kur'ân Dili. 10 Cilt. İstanbul: Eser Neşriyat ve Dağıtım, 1979.

Zebîdî, Murtaza Muhammed. Tâcu'l-'arûs min cevâhiri'l-kâmûs. 40 Cilt. b.y.: Dâru'l-Hidâye, ts. 